\title{
Working
}

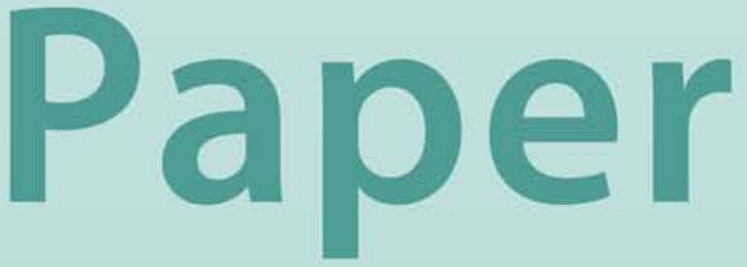




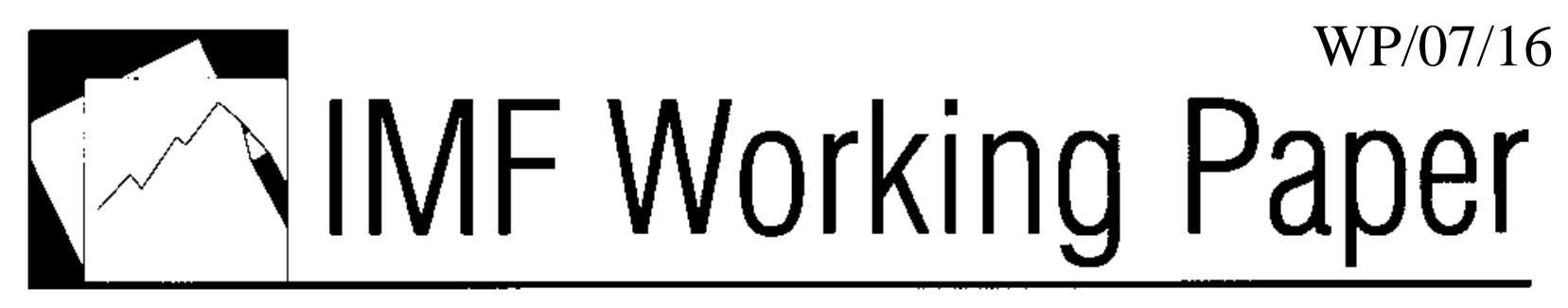

Does Trade and Technology Transmission Facilitate Inequality Convergence?

An Inquiry into the Role of Technology in Reducing the Poverty of Nations

Gouranga Gopal Das 


\title{
IMF Working Paper
}

IMF Institute

\section{Does Trade and Technology Transmission Facilitate Inequality Convergence? An Inquiry into the Role of Technology in Reducing the Poverty of Nations \\ Prepared by Gouranga Gopal Das ${ }^{1}$}

Authorized for distribution by Andrew Feltenstein

January 2007

\begin{abstract}
This Working Paper should not be reported as representing the views of the IMF. The views expressed in this Working Paper are those of the author(s) and do not necessarily represent those of the IMF or IMF policy. Working Papers describe research in progress by the author(s) and are published to elicit comments and to further debate.

Based on stylized evidence showing variation of the Gini coefficient of income inequality across skill cohorts and on the rapid rise in trade in technology-intensive goods, the ripple effects of technology transmission and income inequality are explored in a global Computable General Equilibrium (CGE) framework. An exogenous technology shock transmitted via trade from the United States induces productivity growth in developing regions. This spillover capture-aided by absorptive capability, better governance and institutions, technological symmetry and social acceptance-causes income to increase and income inequality to decline. The conjoined parameters retard growth's inequality-enhancing effect and thus facilitate long-run convergence of inequality between nations.

JEL Classification Numbers: $\quad$ D3, I3, O1

Keywords: Inequality, Spillover, Governance, Institution, Gini Coefficient, Skill Cohorts, Growth

Author’s E-Mail Addresses: ㅁasgouranga@yahoo.com; ggd@hanyang.ac.kr

\footnotetext{
${ }^{1}$ Department of Economics, Hanyang University, South Korea. The initiation stage of writing this paper was during the author's short stint at the IMF, in Washington, DC, during winter 2005. Acknowledgements are due to the Global Development Network and the IMF for financial support under the IMF-GDN Network's fifth Visiting Scholars Program. The hospitality of the IMF is gratefully appreciated. Also, the academic support of Andrew Feltenstein at the IMF needs special mention. Special thanks go to Alan Powell. However, usual caveat applies.
} 
I. Analyzing Trade-Income Inequality Linkages: Lacunae in the Literature........................ $\underline{3}$

II. Trade, Technology, and Income Inequality: Background Quantitative Evidence ............... $\underline{5}$

A. Incidence of Income Inequality Across Skill Cohorts: Macro Lens ........................... $\underline{5}$

B. Interoccupational Inequality and Trade Openness: Empirical Support .......................

C. Growth in Trade: Global, Regional and Sectoral Patterns .....................................12

III. Trade, Technology, and Inequality: Theory Hits Facts ..............................................14

IV. A Model of Technology Spillover, Capture, and Reduction in Income Inequality ..........16

A. Trade-Mediated Technology Transfer and Effective Capture....................................16

B. A Stylized Mechanism for Income Inequality Reduction via Spillover ..................... 19

V. Database, Methodology, and Framework ............................................................. 22

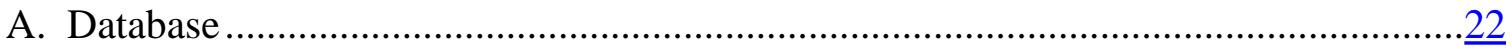

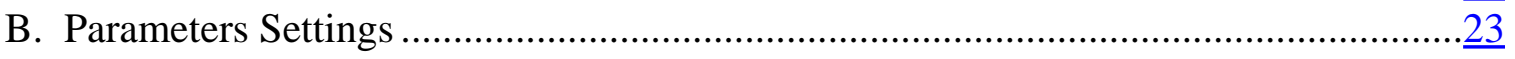

VI. Simulation Design, Scenarios, and Results ........................................................... 25

A. Technology Spillover and Inequality Scenario: Pure Productivity Shock.....................26

B. Senarios of Trade Policy Configurations ..............................................................29

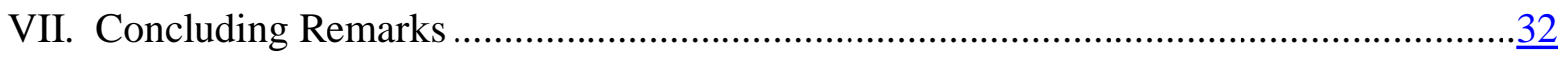

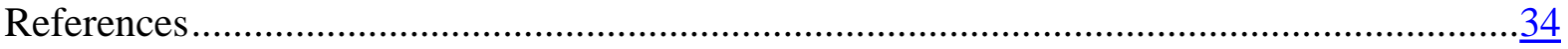

Tables

1. Regional Gini Indexes Across Skill Cohorts .............................................................

2. Average Annual Growth Rates for Global Trade in Broad Manufactures Sectors,

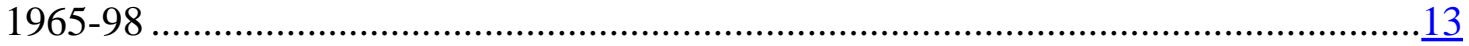

3. Average Annual Growth Rates for Regional Trade in Broad Manufactures,

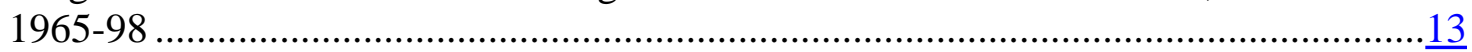

4. Technology Achievement Index for Selected GTAP Regions ...................................... $\underline{15}$

5. Sectoral and Regional Aggregations Used for the Implementation.................................23

6. Simulated Regional Effects of 4 Percent TFP Shock in the Hi-Tech Sector in the US on Selected Macroeconomic Variables (percent changes) .........................................

7. Values of Economy-Wide Embodiment-Indexes, Spillover Coefficients, and Parameters for Governance, Social Acceptance, Capture, and Congruence ..................................27

8. Simulated Regional Effects on Aggregate Performance .............................................28

9. Values of Original (Base Case) and Ex Post (Post-Simulation) Gini Coefficients ............29

10. Simulated Regional Effects on Aggregate Performance Without Sequencing..................

11. Simulated Impact on Sectoral Total Factor Productivity (TFP), Growth, Output and

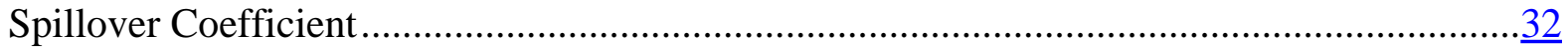

Figures

1-3. Line Fit Plots 
"Reducing barriers to trade is not enough to fulfill the development promise of Doha. Trade must be part of a larger development strategy for each country, a strategy that includes attention to macroeconomic policy, infrastructure, education, and health as well as to accountable and responsible governance. These elements of investment climate take time to develop but are essential for growth and poverty reduction and are crucial to make a sound strategy pay its growth and poverty reduction dividends." —Nicholas Stern, Chief Economist and Senior Vice President, World Bank, "Global Economic Prospects—Realizing the Development Promise of Doha Agenda: 2004."

\section{ANALYZING TRADE-INCOME INEQUALITY LINKAGES: LACUNAE IN THE LITERATURE}

Is there any cause, sui generis, for trade per se reducing inequality across nations? We investigate this research question in the light of the above quotation. The relationship between long-term sustained productivity growth and distribution is contingent, inter alia, on human capital formation, on structural reforms and on trade reforms in conjunction with sound macroeconomic policies (Global Economic Prospects 2004, p.239). Many researchers have highlighted the nexus of trade, growth, and poverty and have stressed that economic growth is pro-poor (Berg and Krueger 2003; Dollar and Kraay 2002, 2003; World Bank Development Policy Group, Global Economic Prospects 2004b; and World Bank, World Development Report 2000/2001, 2004a, among many). Renewed interest in the impact of trade reforms on income inequality and its importance in poverty reduction have dominated the policy discussion (Gunter, Cohen, and Lofgren 2005; Robinson and Lofgren 2005).

According to Winters, McCulloch, and McKay (2004), although there are diverse findings on the impact of trade liberalization on poverty reduction, over the medium to long term, trade liberalization seems likely to alleviate poverty. There is ample empirical evidence in the literature that trade helps nations to embark on a higher growth path and hence affects income distribution (Grossman and Helpman 1991; Dollar and Kraay 2002; Frankel and Romer 1999; Richardson 1995; and Helpman 2002). ${ }^{2}$ Chakrabarti (2000) has shown that trade and overall income inequality as proxied by national Gini coefficients are inversely related. Based on data for the poorest 20 percent of the population for 1965 to 1990, Bleaney and Nishiyama (2004) found that the overall growth rate of an economy and its trade openness are positively correlated with the growth rate of the income levels of the poor. However, given the income distribution, growth reduces income poverty; but if growth leads to a worsening of the distribution, then poverty might increase (Deininger and Squire 1996; Bourguignon 2004).

According to Bourguignon (2004), the triad of growth, inequality and poverty is all important for chalking out an effective development strategy. For economic growth to be pro-poor, it is imperative that the poor should have access to the fruits of modern science and cutting-edge technologies, to an adequate socio-institutional set-up, and to a constellation of macroeconomic fundamentals such as human capital, governance, education, and infrastructure. Given the entitlements to endowments, all of these facilitate development of functional capabilities in the poor nations which enable them to grow (Sen, 2004). According to Bussolo and O’Connor (2002), growth's effect on the direction of change in inequality (widening or shrinking) depends on various 'initial conditions, like human

2 During the past few years and at present, debates on the effect of trade on wage inequality have continued. Especially, it has been argued that skill vis-à-vis unskilled wage inequality has been caused by a concomitant rise in trade under the onslaught of globalization. Thus, globalization is a cause behind wage inequality (Wood 1994, Bhagwati and Kosters 1994; Marjit and Acharya 2003; and Milanovic and Squire 2005). However, trade and wage inequality linkages are not explored here. 
capital endowments, access to credit by low-income households, and policies that may influence the distribution of benefits from growth (p.17).' An immensely important role for poverty-alleviation has been ascribed to technological advancement, mention Sachs (2005), Bussolo and O'Connor (2002) and Keynes (1930). For the developing regions, the role of knowledge-capital and its propagation is of utmost importance for their evolution in a growth trajectory on a sustained basis. Such enhancement makes the poor less vulnerable to fierce global competition and enables them to escape from barnacles of despair of poverty. Recently, the dynamism of the 'platform technologies' viz., information and communication technology (ICT), of bio-technological progress, and of nanotechnology in inducing productivity and economic growth, has received major attention (Millennium Project Report 2005: pp. 92-93, Bussolo and O’Connor 2002). De Janvry et al. (2000) have simulated the positive effect of $10 \%$ total factor productivity (TFP) improvement in agriculture on poverty reduction for Asia, Africa and Latin America.

In China, changes in the size of landholdings, improvements in schooling, and technology adoption have contributed positively to farm and non-farm income (Huang and Rozelle 1996; Huang et al. 2004; Lin 1999). Considering Madagascar, an impoverished rice economy, Minten and Barrett (January 2005) have shown the favorable impact of agricultural technology adoption and consequential higher crop yields on poverty reduction.

Trade is one important conduit for reaping the boons of technology spillover from rich partners to recipients (Keller 2004; Coe and Helpman 1995; Bayoumi, Coe, and Helpman 1999). Thus, trade and technology policy is a subset of a broader macroeconomic agenda for fostering pro-poor growth. Although the effect of trade per se on income inequality cannot directly be translated into its impact on poverty reduction (Winters, McCulloch, and McKay 2004), if following growth income distribution does change, it reduces poverty. Ravallion (2001) has shown that if income inequality is reduced with accompanying growth, the median rate of decline in poverty is approximately $10 \%$ per year.

In this paper, however, we account for the reduction of inequality and poverty of a nation by emphasizing the role of socio-institutional factors; viz., human capital based absorptive capacity induced by skill intensity, governance, R\&D and social acceptance parameters. We show that the initial income distribution matters for economic growth; given the scope of trade liberalization and trade-mediated technology spillover, with a proper constellation of socio-institutional factors and absorptive capacity, the initial income situation could be made more egalitarian. According to Bussolo and O’Connor (2002: p.13), 'technology seldom works in vacuum; it is embedded in social system..., [and], it usually involves adjustments in accustomed practices.' It is argued that failure to establish an appropriate national institutional and policy framework makes it harder to realize the potential trade-induced benefits (Gunter, Cohen, and Lofgren 2005). The more the technology and knowledge frontier is pushed forward, given the constellation of accompanying supportive factors, the lower is the income inequality and incidence of poverty across citizenry. As has been rightly pointed out in the context of tropical Sub-Saharan Africa by Sachs et al. (2004), achieving poverty reduction entails removing obstacles of bad health, low level of education, dearth of foreign aid and poor governance.

This paper offers a model to elicit heuristically how exogenous technological change, its adoption and the induced improvement in productivity can affect the income inequality, poverty and welfare of nations. A global computable general equilibrium (CGE) model, the Global Trade Analysis Project's (GTAP's) trade model (Hertel ed. 1997), with 78 regions $\times 57$ sectors, is suitable for studying multisectoral, multi-regional linkages with international spillover. Thus, the standard model is augmented in order to provide an assessment of the policy shocks. We formally offer an analytical treatment of the nexus between income inequality and spillover capture. Specific objectives are: (a) to estimate the 
impact of technical changes and its trans-border propagation on income inequality under different configurations of trade policy; and (b), to assess the role of human capital, and socio-institutional features in reducing income inequality.

Section 2 unfolds some stylized facts. Section 3 introduces the conceptual framework. Section 4 spells out the model. Methodology and Data are described in section 5. Section 6 presents the simulation scenarios followed by analysis of the results. Section 7 summarizes the findings.

\section{TRADE, TECHNOLOGY AND INCOME INEQUALITY: BACKGROUND QUANTITATIVE EVIDENCE}

In this section, using the global database of the Global Trade Analysis Project (GTAP) and the World Bank's database, we present quantitative evidence on interregional openness to trade and on income disparities across different labor categories in different regions. These, by making cross-country comparisons, provide a 'macro' lens for viewing globalization, trade and poverty. To offer a ' $m i c r o$ ' view, we also present evidence on growth patterns in sectoral trade. The use of the GTAP database is motivated by the fact that the model used for simulation is a version of GTAP suited specifically to our purpose. Thus to derive stylized evidence, we exploit features of both the large disaggregated GTAP database of 78 regions and 57 sectors and of its aggregated lower-dimensional 12 sector $\times 14$ region version.

\section{A. Incidence of Income Inequality Across Skill Cohorts: Macro Lens}

Besides capturing an important aspect of the overall income distribution, a nation's Gini coefficient also reflects the extent of poverty in it, and is the most widely used aggregate measure of income inequality. It can be envisaged that if an economy has an egalitarian distribution then the fruits of economic growth, whatever be the source, permeate through the overall fabric of the society because they are targeted well by public policy. Thus, via a trickle-down effect, improvements in prosperity reach different strata leading to partial or full eradication of income poverty. If, on the contrary, a society maintains an inegalitarian income distribution, there will be imperfection in absorbing the fruits of economic growth as every dollar generated due to growth bypasses the poor segment of the society. Ravallion (1994) finds that rankings of inequality and poverty indices are similar and they move in unison with each other. Also, using a poverty-growth-inequality triangle, Bourguignon (2003, p. 2) showed that changes in income distribution could be attributed to the growth effect (given unchanged relative income distribution) and the distributional effect (given unchanged mean income).

GTAP's global database Version 5.4 provides us with comprehensive global trade data with income split between two labor types: skilled and unskilled (Dimaranan and McDougall 2002 and 2003). ${ }^{3}$ There are considerable heterogeneities within these two groups and so, we could expect considerable heterogeneity in the impacts of trade on inequality and poverty within both the skilled and unskilled populace (Ravallion 2004). The national Gini index does not capture the inequality across income groups differentiated according to skill content. In order to trace whether people in diverse strata

\footnotetext{
${ }^{3}$ Version 6 or beta release of the GTAP database incorporates more regional split whereas number of sectors remain the same. During the time of conducting research, this was not available. However, this does not undermine our purpose because those regions are not subject of study in this paper-rather; those are clustered into composite rest-of-the-world region.
} 
capture the impacts of trade and technology policy evenly or unevenly, we need to know the extent of inequality among people in disparate income groups or skill categories.

Milanovic and Squire (2005) have considered inter-occupational and inter-industry wage inequality and have found that for poor nations, tariff reduction (import liberalization) is associated with higher inequality in both cases. Their study is based on labor market features viz., 'syndicalization' or trade union premium. Unlike them, we calculate an inter-occupational Gini index based on educational attainment and skill content as spelt out below.

As per Yitzhaki (2002), any inequality index can be decomposed into components reflective of the extent of inequality among different income strata—poor and rich classes-so that the decomposition, like poverty indices, provides necessary information about within and between-groups inequality. Using the data available on the income Gini (spatial and temporal distribution), we offer statistical evidence on income inequality across skill cohorts based on the labor payments matrix in the GTAP database. Yitzhaki (2002) decomposes the national Gini index into three components for two categories of population — rich and the poor. Typically, to suit our purpose we adapt Yitzhaki's methodology of decomposition for finding inter-occupational Gini indexes for the two skill groups as representative of different income classes. Within each cohort, 'skilled' are assumed to be 'non-poor' or relatively affluent, whereas the 'unskilled' are assumed to be 'poor' or relatively less affluent. Between these cohorts, there are substantial income differences that are reflected in national Gini measures. These are especially true for countries like India, China or South Korea under extreme or moderate poverty (see Sachs 2005).

Following Yitzhaki (2002), we now present the modified version of Gini decomposition for computing the inter-skill Gini inequality. The overall Gini coefficient of income $\left(\mathrm{G}_{\mathrm{yo}}\right)$ is written component-wise as,

$$
\mathrm{G}_{\mathrm{yo}}=\mathrm{P}_{\mathrm{s}} \mathrm{S}_{\mathrm{ys}} \mathrm{G}_{\mathrm{ys}}+\mathrm{P}_{\mathrm{u}} \mathrm{S}_{\mathrm{yu}} \mathrm{G}_{\mathrm{yu}}+\mathrm{G}_{\text {between }}
$$

where $\mathrm{G}_{\mathrm{yi}}=$ Gini income coefficient for $\mathrm{i}^{\text {th }}$ category, with $\mathrm{i} \in\{\mathrm{o}, \mathrm{s}, \mathrm{u}\}$ in which $\mathrm{o} \Leftrightarrow$ overall; $\mathrm{s} \Leftrightarrow$ skilled (assumed rich) and $\mathrm{u} \Leftrightarrow$ unskilled (assumed non-rich or poor);

$\mathrm{G}_{\text {between }}=$ between-groups or skilled versus unskilled inequality;

$\mathrm{P}_{\mathrm{i}}=$ the proportion of the of $\mathrm{i}^{\text {th }}$ category in the population for $\mathrm{i} \in\{\mathrm{s}, \mathrm{u}\}$ and $\mathrm{P}_{\mathrm{s}}=1-\mathrm{P}_{\mathrm{u}}$; and

$\mathrm{S}_{\mathrm{yi}}=$ the share in overall income of income of category i for $\mathrm{i} \in\{\mathrm{s}, \mathrm{u}\}$.

Thus, $\mathrm{S}_{\mathrm{yi}}=\frac{\mathbf{P}_{\mathbf{i} \mathbf{i}}}{\overline{\mathbf{y o}_{\mathbf{i}}}}$ and $\mathrm{S}_{\mathrm{ys}}=1-\mathrm{S}_{\mathrm{yu}}$

in which

$\mathbf{y}_{\mathbf{0}}=$ mean income of overall labor categories;

$\overline{\mathbf{y}_{\mathbf{i}}}=$ mean income of $\mathrm{i}^{\text {th }}$ labor category.

Also, based on Yitzhaki (2002) we get that $G_{\text {between }}=P_{u}-S_{y u}$.

In the equations above, $\mathrm{G}_{\mathrm{yo}}$ is obtained from the World Bank's World Development Indicators (2003, 2005). $S_{y s}$ and $S_{y u}$ are calculated from the disaggregation of labor payments in version 5.4 of GTAP's database. It needs to be mentioned that the GTAP database's skilled-unskilled income shares are based on average years of education, which in turn are based on Barro and Lee (1996). Das (2002) shows that different measures of educational attainment can be reconciled with GTAP's labor payment shares across skill categories. This allows us to take the tertiary enrolment ratio (percentage of population in age group 15-64 having tertiary education or more) as a proxy for the share of skilled personnel $\left(\mathrm{P}_{\mathrm{s}}\right)$ in the population. These enrollment proportions are taken from the World Bank's 
World Development Indicators (2003, 2005). Thus, using (2), we can find the value of $\mathrm{G}_{\text {between }}$ to be substituted into Equation (1). As between-group inequality can be decomposed into poverty gap, affluence gap and poverty-affluence gap (Yitzhaki 2002; Sen 1976, 1986), we make an assumption of approximation that

$$
\mathrm{G}_{\text {between }}=\left|\mathrm{G}_{\mathrm{ys}}-\mathrm{G}_{\mathrm{yu}}\right|
$$

Now, using (1) and (2), after algebraic manipulation we can compute $\mathrm{G}_{\mathrm{ys}}$ that is reported below

$$
\mathbf{G}_{\mathbf{y s}}=\frac{\mathbf{G y o}_{\mathbf{y}}-\left(1-\mathbf{P u S}_{\mathbf{u} \mathbf{u}) \mathbf{G} \text { between }}\right.}{\text { PsSys }_{\mathrm{s}}+\mathbf{P u S}_{\mathbf{u} u}}
$$

and $\mathrm{G}_{\mathrm{yu}}$ is computed using (3).

The computed Gini coefficients across the skilled and unskilled labor categories for the GTAP noncomposite, single regions, are reported in Table 1. From Table 1, it is evident that across almost all regions, compared to the Gini index for the skilled labor force, the computed Gini coefficient is lower for the unskilled labor category. ${ }^{4}$ It is to be noted that these findings are based on skill composition and on application of Yitzhaki's (2002) method to the global GTAP database. Now, we explore the role of trade reform on income inequality.

\section{B. Interoccupational Inequality and Trade Openness: Empirical Support}

The trade orientation measure (OPEN) used for our analysis is regional "Export (X) plus Import (M)" normalized by regional GDP [i.e., (X+M)/GDP]. Each region is indexed by ' $r$ '. In order to check the relationship between trade openness and GDP, we run an OLS regression under a loglinear specification for a sample of 78 regions in the GTAP database as below:

$$
\ln \mathrm{GDP}(\mathrm{r})=\alpha+\beta \ln \mathrm{OPEN}(\mathrm{r})+\varepsilon(\mathrm{r}) \quad(\mathrm{r}=1, \ldots, 78)
$$

Data on the concerned variables are extracted from GTAP database.

The estimated equation is given below (with Student's t values in parentheses):

$$
\begin{aligned}
& \ln \mathrm{GDP}(\mathrm{r})=-0.0605+1.035 \ln \mathrm{OPEN}(\mathrm{r}), \mathrm{R}^{2}=0.91, \text { S.E. }=0.55 \\
&(-0.155) \\
&(29.04)
\end{aligned}
$$

We observe that GDP growth is positively related to 'trade openness' and statistically significant. ${ }^{5}$ This positive association is evidenced amply in the current literature (McCulloch, Winters, and

\footnotetext{
${ }^{4}$ Alternatively, for computing the Ginis, for $\mathrm{P}_{\text {poor }}$ we have also taken percentage of people below national poverty line and $50 \%$ of median income for developed nations as proxy of proportion of people below poverty line and hence, poor. This measure is not accurate because we do not know $\mathrm{P}_{\text {rich }}$ and that creates computational problem. However, because the GTAP database has skilled income payment share we adopt tertiary education enrolment level as proxy of skill population. Considering data on percentage of population below poverty line of bottom, we derived the measure of income inequality across income groups. But, we do not report those for parsimony. However, this does not undermine our purpose because GTAP's skill decomposition is based on educational attainment data as described in Barro-Lee (1996).

${ }^{5}$ An alternative specification using a linear relationship under OLS shows the same causality and direction. The value of $R^{2}=0.82$.
} 
Table 1. Regional Gini Indexes across skill cohorts

\begin{tabular}{|c|c|c|c|}
\hline $\begin{array}{c}\text { Matched } \\
\text { GTAP Regions }\end{array}$ & $\begin{array}{c}\text { Gini Index } \\
\text { (Overall) }\end{array}$ & Gini_skl & Gini_unskl \\
\hline Name & $\overline{\text { Go }}$ & $\overline{\text { Gys }}$ & Gyu \\
\hline Albania & 28.2 & 26.51 & 0.08 \\
\hline Argentina & 52.2 & 78.55 & 62.14 \\
\hline Australia & 35.2 & 36.85 & 21.56 \\
\hline Austria & 30.5 & 32.04 & 17.03 \\
\hline Bangladesh & 31.8 & 36.15 & 15.38 \\
\hline Belgium & 25 & 16.41 & 1.75 \\
\hline Brazil & 59.1 & 81.25 & 51.01 \\
\hline Bulgaria & 31.9 & 49.96 & 40.10 \\
\hline Canada & 31.5 & 36.35 & 23.29 \\
\hline Chile & 57.5 & 91.13 & 72.88 \\
\hline China & 40.3 & 48.76 & 30.91 \\
\hline Colombia & 57.1 & 83.75 & 60.81 \\
\hline Croatia & 29 & 28.45 & 3.36 \\
\hline Czech Republic & 25.4 & 22.07 & 0.17 \\
\hline Denmark & 24.7 & 17.34 & 0.44 \\
\hline Estonia & 37.6 & 50.95 & 38.95 \\
\hline Finland & 25.6 & 12.26 & 15.20 \\
\hline France & 32.7 & 32.44 & 14.21 \\
\hline Germany & 38.2 & 42.84 & 21.73 \\
\hline Greece & 35.4 & 33.46 & 1.47 \\
\hline Hong Kong SAR & 43.4 & 43.11 & 2.23 \\
\hline Hungary & 24.4 & 22.37 & 4.24 \\
\hline India & 37.8 & 45.69 & 24.43 \\
\hline Indonesia & 30.3 & 36.24 & 17.87 \\
\hline Ireland & 35.9 & 36.07 & 14.52 \\
\hline Italy & 36 & 36.50 & 15.71 \\
\hline Japan & 24.9 & 17.27 & 2.43 \\
\hline Korea & 31.6 & 36.44 & 29.89 \\
\hline Latvia & 32.4 & 38.98 & 27.46 \\
\hline Lithuania & 36.3 & 48.21 & 34.02 \\
\hline Madagascar & 46 & 53.27 & 36.31 \\
\hline Malawi & 50.3 & 58.20 & 39.95 \\
\hline Malaysia & 49.2 & 74.71 & 57.87 \\
\hline Mexico & 51.9 & 72.43 & 48.40 \\
\hline Morocсо & 39.5 & 47.72 & 24.65 \\
\hline
\end{tabular}


Table 1(concluded). Regional Gini Indexes across skill cohorts

\begin{tabular}{|c|c|c|c|}
\hline Matched GTAP Regions & $\begin{array}{c}\text { Gini Index } \\
\text { (Overall) }\end{array}$ & Gini_skl & Gini_unskl \\
\hline Name & Go & Gys & Gyu \\
\hline Mozambique & 39.6 & 44.86 & 26.49 \\
\hline Netherlands & 32.6 & 30.48 & 11.62 \\
\hline New Zealand & 36.2 & 43.37 & 33.03 \\
\hline Peru & 46.2 & 62.16 & 38.30 \\
\hline Philippines & 46.1 & 66.40 & 46.56 \\
\hline Poland & 31.6 & 39.67 & 27.05 \\
\hline Portugal & 38.5 & 39.12 & 17.10 \\
\hline Romania & 30.3 & 40.77 & 26.23 \\
\hline Russia & 45.6 & 65.28 & 55.71 \\
\hline Singapore & 42.5 & 46.18 & 11.07 \\
\hline Slovak Republic & 25.8 & 23.60 & 2.18 \\
\hline Slovenia & 28.4 & 31.14 & 18.63 \\
\hline South Africa & 59.3 & 82.25 & 56.01 \\
\hline Spain & 32.5 & 33.28 & 17.28 \\
\hline Sri Lanka & 34.4 & 38.82 & 17.97 \\
\hline Sweden & 25 & 19.97 & 6.93 \\
\hline Switzerland & 33.1 & 28.91 & 4.78 \\
\hline Taiwan Province of China & 40 & 38.33 & 0.87 \\
\hline Tanzania & 38.2 & 42.06 & 31.57 \\
\hline Thailand & 43.2 & 63.04 & 45.44 \\
\hline Tunisia & 41.7 & 52.74 & 28.20 \\
\hline Turkey & 40 & 50.29 & 28.09 \\
\hline Uganda & 37.4 & 42.70 & 29.62 \\
\hline United Kingdom & 36 & 37.98 & 21.43 \\
\hline Uruguay & 44.8 & 67.05 & 50.13 \\
\hline United States & 40.8 & 45.82 & 34.66 \\
\hline Venezuela & 49.1 & 71.15 & 50.31 \\
\hline Viet Nam & 36.1 & 44.21 & 27.02 \\
\hline Zambia & 52.6 & 62.45 & 41.69 \\
\hline Zimbabwe & 56.8 & 70.74 & 42.52 \\
\hline
\end{tabular}

Source: Author's calculation using GTAP database. 
Cirera 2001; ${ }^{6}$ Global Economic Prospects 2004; Frankel and Romer 1999; Edwards 1997; Cline 2004). Higher export growth and openness is associated with higher GDP. Specifically, the pathways of positive effects are via imported inputs embodying advanced technology, learning effect and efficiency.

Given the effect of trade orientation on growth of national income, to trace the effects of trade on inequality we estimate the following equation separately for each Gini value for different skill levels and for the composite one:

$$
\ln \mathrm{G}_{\mathrm{yi}}(\mathrm{r})=\gamma+\delta \ln \mathrm{OPEN}(\mathrm{r})+\mu(\mathrm{r})
$$

with $\mathrm{i} \in\{\mathrm{o}, \mathrm{s}, \mathrm{u}\}$ in which $\mathrm{o} \Leftrightarrow$ overall; $\mathrm{s} \Leftrightarrow$ skilled (assumed rich) and $\mathrm{u} \Leftrightarrow$ unskilled (assumed nonrich or poor). The slope coefficient measures the elasticity of respective Gini coefficients with respect to regional trade orientation. The fitted regression line and the t-statistic values for the estimated slope coefficients for each $\mathrm{i}^{\text {th }}$ category are given below:

$$
\begin{aligned}
\ln \mathrm{G}_{\mathrm{yo}}(\mathrm{r})= & 4.128+(-) 0.121 \ln \operatorname{OPEN}(\mathrm{r}), \mathrm{R}^{2}=0.08, \text { S.E. }=0.234 \\
& (18.20) \quad(-2.29) \\
\ln \mathrm{G}_{\mathrm{ys}}(\mathrm{r})= & 4.437+(-) 0.165 \ln \operatorname{OPEN}(\mathrm{r}), \mathrm{R}^{2}=0.05, \text { S.E. }=0.426 \\
& (10.77) \quad(-1.73) \\
\ln \mathrm{G}_{\mathrm{yu}}(\mathrm{r})= & 4.726+(-) 0.349 \ln \operatorname{OPEN}(\mathrm{r}), \mathrm{R}^{2}=0.08, \text { S.E. }=0.643
\end{aligned}
$$

These are shown in Figures 1, 2 and 3 respectively.

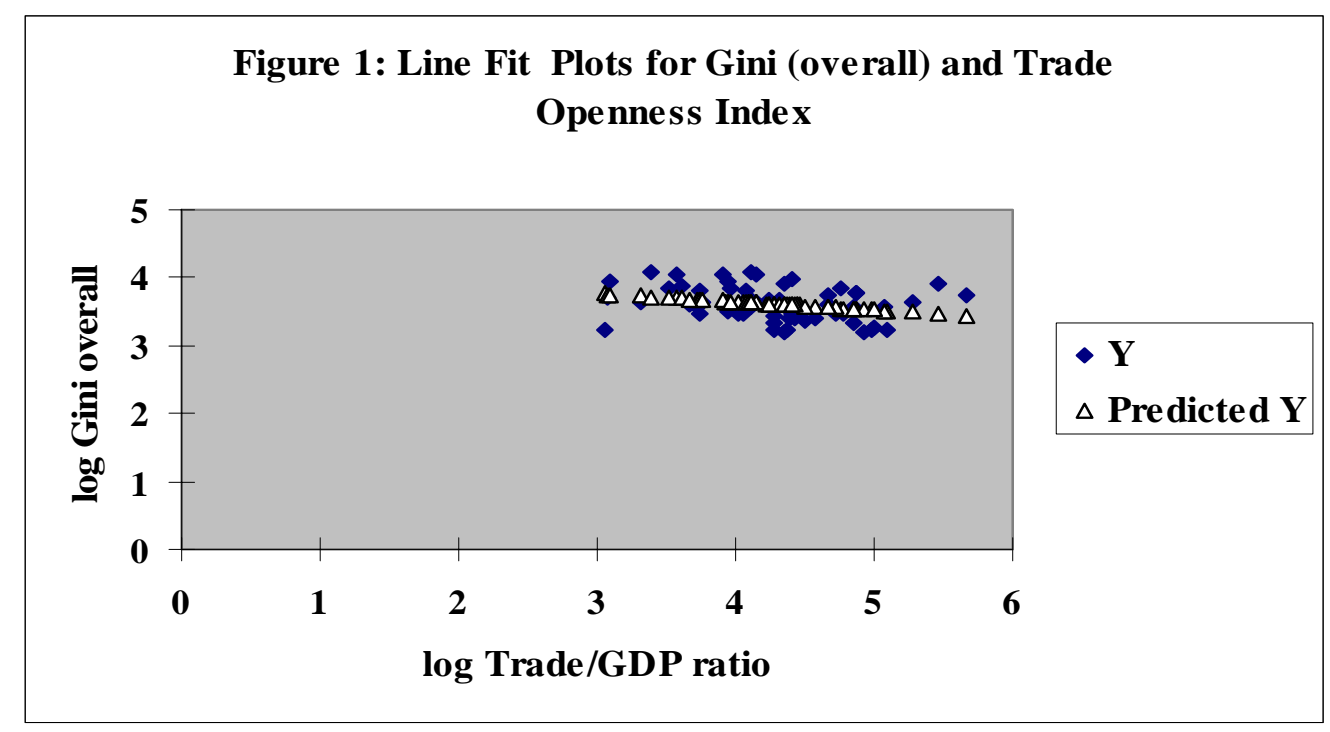

\footnotetext{
${ }^{6}$ Chapter 2: The Debate over Trade Liberalization. Trade Liberalization and Poverty: A Handbook, CEPR.
} 


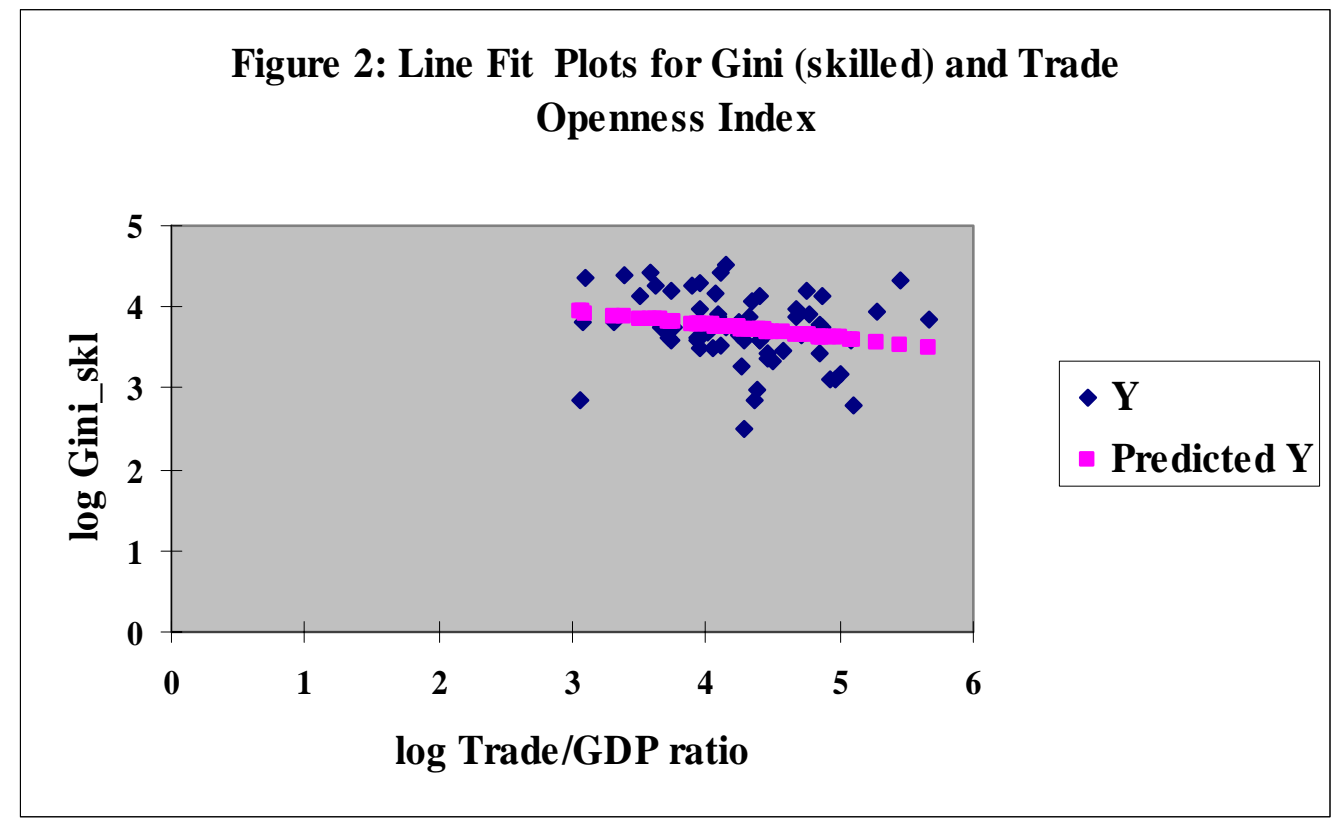

Figure 3: Line Fit Plots for Gini (unskilled) and Trade Openness Index

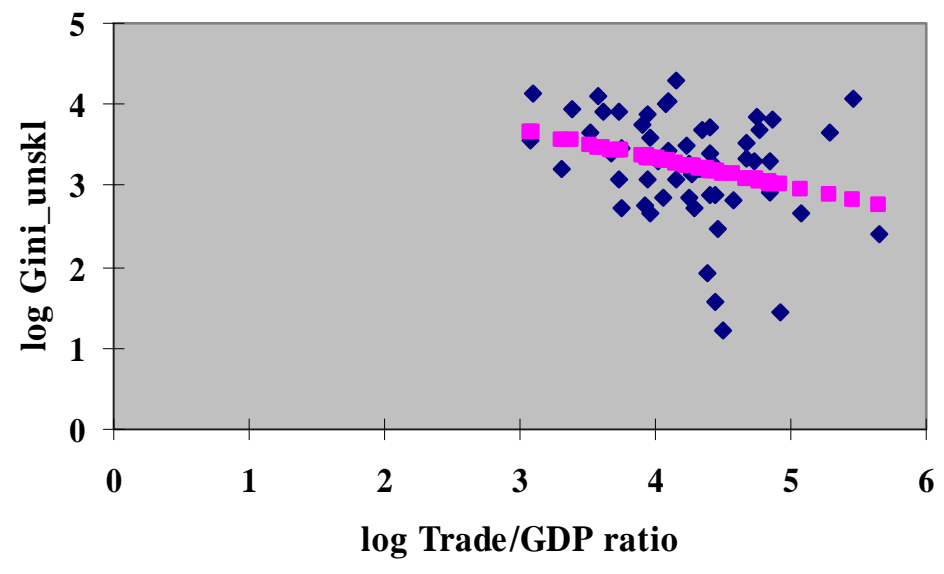

Thus we see that there exists a statistically significant inverse relationship between trade and income inequality. We can infer that trade reduces income inequality and hence, improves within-group income distribution - overall, and for both skilled and unskilled income categories. From (6a), (6b) and (6c) we see that greater participation in foreign trade (i.e., a higher trade to GDP ratio) reduces income inequality for all the categories. The point estimates signify that an increase in a region's trade openness index by one percent, on average, will tend to lower the relevant inequality indexes by $0.12 \%, 0.17 \%$ and $0.35 \%$ for the skilled group, the unskilled group and overall respectively. This is due to the growth effect of trade; trade lowers inequality by increasing the income level and causing subsequent growth. 
Note that the effects of trade openness in reducing Gini inequalities within the skilled and within the unskilled groups are different - the regression analysis exhibits that the elasticity of the Gini coefficient for the skilled group is lower than that for the unskilled group. According to Ravallion (1997), the sensitivity of poverty to economic growth depends on initial income inequalities. From our calculation, income inequality is more pronounced in the skilled labor groups than in the unskilled groups in the GTAP regions. This implies that the initial income distribution is less egalitarian within the former groups, whereas initial income inequality within the unskilled regional groups is relatively less. The results suggest that for the unskilled, economic growth raises initial income levels and facilitates a faster reduction in inequality. Compared to the case of the skilled with initially high within-group income inequality, trade-induced economic growth has a larger effect on poverty alleviation and on inequality reduction within the unskilled groups.

Evidently, as unskilled labor has a more equal within-group income distribution than skilled labor, trade-induced growth raises the income level and closes the within-group income gaps by a higher percentage. Moreover, it can be said that trade reduces the Gini coefficient for the skilled groups because economic growth induced by the spillover of foreign technology can be absorbed relatively easily by them.

Trade does not necessarily increase wage inequality between skilled and unskilled labor. Rather, there might be a tendency to close the wage gap. This is suggested by Lawrence and Slaughter (1993) whose results show that trade has a dampening effect on wage inequality. Insofar as growth does not worsen income disparities or distribution, a rise in average income due to trade openness will reduce income inequality across skill cohorts and will also reduce poverty.

The above evidence gives us a global picture of income inequality across skill categories. We now turn to a micro view of the rising tide of trade.

\section{Growth in Trade: Global, Regional and Sectoral Patterns}

Since our interest is to explore the role of trade in facilitating inequality convergence, it is worthwhile to explore trade in technology-based sectors in some selected regions. The establishment of Information and Communication Technologies (ICT) and related activities has generated spillover effects in the form of outsourcing of materials and services and splintering (Gordon and Gupta 2004) of industrial activity. With regard to the information technology sector ${ }^{7}$, it has been argued that there has been substantial production fragmentation via FDI inflows (Bonham and Gangnes 2004). GTAP's Version 5.4 database provides us with a time-series trade data for the period 1965-1998 for a subset of variables representing trade in commodities. Considering trade in manufactures, the shares of high-technology goods in manufacturing exports are higher for advanced and semi-industrialized nations (Das 2002). Concentrating on the technology content of different sectors, we consider three broadly defined manufacturing clusters, each sharing some common characteristics, including the intensity of technology in the constituents of each. ${ }^{8}$ These broad sectors are light manufactures, heavy

\footnotetext{
${ }^{7}$ IT products include SITC (revision 2 and 3) classification categories 75, 76 and 776. These are automatic data processing instruments such as computers, calculators, photocopy machines, etc. and also, electronic components including semiconductors, electronic tubes and valves, telecommunications and radio equipment. However, these are not exhaustive but 'representative' classification in the absence of detailed classification and dearth of data.
}

${ }^{8}$ According to the OECD (1997), technology is broadly defined as direct and indirect R\&D embodiment of various types of intermediate inputs and capital goods. 
manufactures, and hi-tech intensive products. In Table 2 we present average annual growth rates of global trade in these sectors according to the GTAP database. ${ }^{9}$ Table 3 gives average annual growth in trade in these broad sectors for some selected regions.

Table 2. Average Annual Growth Rates (percent) for Global Trade in Manufactures Sectors, 1965-1998

\begin{tabular}{lcc}
\hline Broad Group & Average Annual Growth Rates & Exponential Growth Rates \\
\hline Light manufactures & 13 & 11 \\
Heavy manufactures & 12 & 10 \\
Hi-technology cluster & 13 & 12 \\
\hline
\end{tabular}

Source: Author's calculations based on time-series trade data from the GTAP database, Version 6.

Table 3. Average Annual Growth Rates (percent) for Regional Trade in Broad Manufactures, 1965-1998

\begin{tabular}{lccc}
\hline Regions & Light manufactures & Heavy manufactures & Hi-technology \\
\hline Canada & 0.09 & 0.12 & 0.12 \\
China & 0.21 & 0.17 & 0.25 \\
EU (FTA) & 0.11 & 0.10 & 0.11 \\
Hong-Kong SAR & 0.14 & 0.17 & 0.19 \\
India & 0.17 & 0.16 & 0.17 \\
Japan & 0.07 & 0.12 & 0.15 \\
MERCOSUR & 0.19 & 0.16 & 0.16 \\
South America & 0.15 & 0.10 & 0.24 \\
South East Asia & 0.18 & 0.14 & 0.29 \\
United States & 0.10 & 0.10 & 0.11 \\
\hline Source: Auth
\end{tabular}

Source: Author's calculations based on time-series trade data from the GTAP database, Version 6.

From these tables, it is evident that global trade in technology intensive products registered considerable growth. Among the sectors, hi-tech registered the highest growth rate in all the regions except the composite Latin American bloc MERCOSUR. Heavy manufactures trade shows higher average annual growth rates than light manufactures. China, Japan, India and South East Asia have much higher average annual growth rates than the United States and Canada. Thus, it can be inferred that not only the typical advanced nations, but also the upcoming newly industrialized regions have shown an upsurge in trade in technology-intensive products. This compositional change in production structure and trade points to the fact that skill-intensive products are assuming a larger share in world trade. Obviously, this will have an impact on returns to skilled versus unskilled labor. However, so long as the trade-led growth does not worsen intra-group inequality, the rise in average income will not accentuate wage inequality and poverty.

Highlighting India and China, many studies have shown the importance of the provisioning of basic education, health, good governance, the development of infrastructure, and rapid economic growth in freeing people from poverty. All these contribute to the reduction of income inequality. East Asian nations have grown fast with GDP growth being 6.7\% in 2002 (Global Economic Prospects, World Bank 2004). Sustained economic growth in this highly dynamic developing region has reduced poverty - the number of people living below $\$ 2$ a day has fallen from 50\% to 34\% between 1999 and 2002 (The World Bank, November 2004).

\footnotetext{
${ }^{9}$ Average annual growth rates are calculated using Ordinary Least Square (OLS) method.
} 


\section{TRADE, TECHNOLOGY AND INEQUALITY: THEORY Hits FACTS}

Keynes (1930) stressed the role of technological advancement in fostering economic growth as a means to end the problem of poverty in industrialized nations like Britain. This solution depends not only on the creation of new technology, but also in the 'scaling up' of its successes so that it reaches the relatively less skilled or poor segments. But technology alone will not solve the problem of poverty. According to Sachs (2005), there is an absolute need for 'collective action, through effective government provision of health, education and infrastructure, as well as foreign assistance'. However, here we will be emphasizing the role of technology.

The nexus between technological capabilities, institutional quality and reduction in income inequality is a complex one, in theory and in practice as well. According to Dyke (2001), "Poverty can be eliminated within the next 50 years if a broad range of technology - not only information technology - is used as a tool to spark and enhance a comprehensive development strategy that encompasses economic, political, social, and environmental elements (p. 17).” Technology can ameliorate the problems of poor governance and economic distance factors, by increasing productivity and enabling a nation to move ahead by leap-frogging.

Different factors affect the capacity of a given economy to capture the benefits of technological innovation. Effective assimilation depends on the skill intensity of the labor force for unlocking the potential of advanced technology. We refer to this factor as absorption capacity (AC). It depends on education and schooling years (Barro and Lee 1996; Cohen and Levinthal 1989 and 1990; Pack and Westphal 1984, Nelson 1990). Investment in human capital, for instance, can help develop technological capability and human resource development.

Domestic invention and foreign-sourced technological spillovers depend, inter alia, on a country's institutional setting: factors such as political stability and good governance are important (Groot et al. 2004; De Ferranti, et al. 2003). Needless to say, it is through familiarity with each other's habits, institutional factors - such as legal protection of intellectual property rights (IPRs) — and even language/s, that two countries will be able to maximize their benefits from mutual trade. The role of governance and institutional quality along with education in appropriating the diffused spillovers from trade has been discussed in the literature (Schiff and Wang 2002). Here we incorporate institutional factors via a parameter reflecting an index of governance (GP). It is argued that technology transmitted from the source will better deliver its potential benefits to the recipients if the governance qualities of the origin and the client are similar. The more the trading regions are structurally homogeneous or proximate the more is the mutual compatibility of their becoming bilateral trade partners. Thus we specify a binary governance parameter to capture institutional quality in our analysis of technology transfer via trade.

Domestication of foreign technology also depends on indigenous inventive capabilities and on a region's own R\&D effort for building technology infrastructure. According to the Human Development Report (2001, p.2), "the $20^{\text {th }}$ Century's unprecedented gains in advancing human development and eradicating poverty came largely from technological breakthroughs.” Technology achievement differs across nations because of uneven diffusion, inequalities in access to innovation across and between countries, as well as in education and skills. Following the Report, we use its Technology Achievement Index (TAI) for each region and compare the source and the client nations to derive a bilateral technological congruence (TC) parameter. In Table 4, we report the TAI-index for each of the regions that we consider in this paper. 
Table 4. Technology Achievement Index for Selected GTAP Regions*

\begin{tabular}{lc}
\hline Regions & Index values \\
\hline Bangladesh & 0.04 \\
Canada & 0.59 \\
China & 0.30 \\
EU & 0.51 \\
HongKong SAR-Taiwan Province of China & 0.46 \\
India & 0.20 \\
Japan & 0.70 \\
MERCOSUR & 0.34 \\
Other South Asia & 0.12 \\
Rest-of-the-World & 0.25 \\
South America & 0.32 \\
South East Asia & 0.36 \\
Sri Lanka & 0.20 \\
United States & 0.73 \\
\hline
\end{tabular}

Source: Human Development Report 2001, Table A2.1

*For Composite regions, the index is calculated by computing the group average.

This index, focusing on achievements in creation, diffusion, use and development of human capability for adoption, is a broad measure of technological capability and of human development. ${ }^{10}$ From the Table, it is evident that the index values are much higher for developed regions like the United States, Canada, Japan and the EU. For the developing regions, we see relatively higher values for 'dynamic adopters' in East and South-East Asia and some South American countries. However, for some newly industrializing economies, the values of such an index are relatively low because in those countries there are disparities in technological achievement within regions with growth pocketed in some enclaves. ${ }^{11}$

The cultural affinity that determines the degree of social cohesion and acceptance of 'new' technology in a region is assumed to depend on the overall quality of human resource development. We incorporate such an effect via an exogenously specified 'social acceptance (SA) parameter'-a composite measure of human development index representing quality of life.

Conjointly, source and destination-specific TC and GP determine the binary institutional-structural congruence index (SC) which together with the host-nation-specific absorption capacity (AC) and social acceptance (SA) parameters determines the amalgam technology appropriation parameter

\footnotetext{
${ }^{10}$ According to Human Development Report (p. 47, 2001), Technological Achievement is important for human development and the Index correlates with the Human Development Index.

${ }^{11}$ For example, in case of India, there is technological hub like Bangalore, the centre of outsourcing activities and software technology development, but this is not spread in other regions in India uniformly because of low adult literacy rate, low tertiary enrolment rate and uneven diffusion of technology across regions within India. Thus, although a state like Bangalore has high achievement index the overall index for India is low in value.
} 
(TAP). This encapsulates the role of SC, SA and AC to capture the potential benefits of trade-induced technology transfer.

Following Sen $(1981,1993)$, poverty is a combination of failure of entitlements (i.e., lack of command over resources) and capability failure (i.e., inability to transform commodities and resources into useful functioning). Poverty is economic 'unfreedom' (Sen 2002, 2004). Investing in technology and socio-institutional fundamentals helps emancipate people from economic unfreedom. Trade induces technological access and broadens the initial entitlements of resources conducive for growth. In our set-up, the ability to reduce the incidence of poverty depends on the factors constituting the socio-institutional parameters. These factors determine 'capabilities' to overcome the obstacles of poverty and to convert an 'expanded set of entitlements' or access to technological improvement into well-defined action-productivity enhancement and reduction of inequality. Thus, even with accessibility to foreign technology without AC, SA, GP and TC parameters there is scope for capability failure, which might translate into failure of achievement of important functioning. Consequently, this might result in poverty.

This inter-linkage lies at the very basic level of growth-driven poverty reduction because all these factors promote growth and a better investment climate in a region (The World Bank, World Development Report 2005). However, there is a lacuna in the existing literature in the formal treatment of the role of such parameters. This paper fills that vacuum by spelling out a mechanism whereby closing the technological gap via appropriate capture and dissemination facilitates inequality convergence in a nation.

\section{A Model of Technology Spillover, CAPTURE ANd REDUCTION IN INCOME INEQUALITY}

\section{A. Trade-mediated Technology Transfer and Effective Capture}

We now modify an empirical general equilibrium model (the GTAP global trade model) to highlight the roles of certain factors in assimilating the technology ferried via traded intermediates. These factors are: human-capital induced skill, quality of governance, and structural congruence between the advanced source and the less developed recipient nations.

Current state-of-the-art technologies and their recent vintages are invented in the developed countries (DCs). These are embodied in the commodities produced using the new 'ideas' and spill over to the destinations through bilateral trade linkages. ${ }^{12}$ Low-income nations depend on foreign technologies originating mainly in the industrialized nations. Their growth and development depend on their capabilities for effectively absorbing the diffused technology. This type of trade-mediated technology transfer occurs via intermediates (Hayami and Ruttan 1985; Meijl and Tongeren 1998; Das 2000). Embodiment of such technological knowledge occurs in hi-technology intensive products.

Following an exogenous technological improvement in a unique sector of one region, all other sectors in that region, and all sectors in other regions trading with it, experience endogenous TFP

12 Thus, international trade in commodities facilitates propagation of superior 'technologies' embodied in those traded goods and services (Dietzenbacher 2001; Eaton and Kortum 1996; Keller 2001, 2004; World Development Report, The World Bank, 1999 for empirical evidences). The nexus between relative income level and the growth rate of the trading partners has been discussed at length (for example, Schiff and Wang, 2004). Role of FDI in technology transfer is also emphasized in the literature. However, the primary emphasis being on the trade flows in the medium-run, we focus solely on trade as a vehicle of advanced technology. 
improvement via technology embodied in intermediate inputs. The flow to other sectors of the source region is the domestic spillover following the exogenous technological change within it. The flow to other regions is the trade-induced spillover. The amount of trade-induced knowledge spillover from a source sector in the innovating region to a particular sector in a client region depends on the relevant input-specific trade intensities of production.

Embodiment indexes are defined in terms of trade intensities for different specific material inputs. We define such an index $\left[\mathrm{E}_{\mathrm{ijrs}}\right]$ as the flow $\left[\mathrm{F}_{\mathrm{irjs}}\right]$ of imported intermediate produced in sector ' $\mathrm{i}$ ' in source region ' $r$ ' that is exported to firms in sector ' $j$ ' in recipient region ' $s$ ' per unit of composite intermediate input of ' $\mathrm{i}$ ' used by sector ' $\mathrm{j}$ ' in destination ' $\mathrm{s}$ '. The latter $-\mathrm{M}_{\mathrm{ijs}}-\mathrm{is}$ a simple aggregate of nominal values and is the total usage of intermediate input ' $\mathrm{i}$ ' by sector ' $\mathrm{j}$ ' in region ' $\mathrm{s}$ '. Thus,

$$
E_{i r j s}=F_{i r j s} / M_{i j s}
$$

The governance parameter $\left(\mathrm{GP}_{\mathrm{rs}}\right)$, it is measured by the following function:

$$
\mathrm{GP}_{\mathrm{rs}}=\min \left[1, \mathrm{GP}_{\mathrm{s}} / \mathrm{GP}_{\mathrm{r}}\right]
$$

According to (8), if destination's' has higher GP than that of source ' $r$ ' (i.e., $\mathrm{GP}_{\mathrm{s}}>\mathrm{GP}_{\mathrm{r}}$ ), then the governance structure of ' $\mathrm{s}$ ' is conducive for effective utilization of the transferred technology and $\mathrm{GP}_{\mathrm{rs}}=1$. Otherwise, if the client region lags in its quality of governance behind the advanced source [i.e., $\mathrm{GP}_{\mathrm{s}}<\mathrm{GP}$ ] , then $\mathrm{GP}_{\mathrm{rs}}<1$ and 's' has a lower ability to absorb the technology. (Note that $0 \leq \mathrm{GP}_{\mathrm{rs}} \leq 1$ for all $\left.\mathrm{r}, \mathrm{s}\right)$.

Analogously, the technological congruence factor is constructed as binary variable $\left(\mathrm{TC}_{\mathrm{rs}}\right)$ measuring proximity or closeness between the source and the client regions ' $r$ ' and's'. Thus,

$$
\mathrm{TC}_{\mathrm{rs}}=\min \left[1, \mathrm{TC}_{\mathrm{s}} / \mathrm{TC}_{\mathrm{r}}\right]
$$

Here also, $\mathrm{TC}_{\mathrm{rs}} \in[0,1]$, with zero implying that destination region ' $\mathrm{s}$ ' is further away from the invention frontier of the source nation ' $\mathrm{r}$ ' than for values of $\mathrm{TC}_{\mathrm{rs}}>0$. Note that $\mathrm{TC}_{\mathrm{rs}}=1$ implies maximal proximity.

Social acceptance indexes $\left(\mathrm{SA}_{\mathrm{s}}\right)$ are given by:

$$
\mathrm{SA}_{\mathrm{s}}=\min \left[1, \frac{\mathrm{SAs}}{\text { SAthreshold }}\right]
$$

This implies that if any region has a larger magnitude of social acceptance (i.e., of human development) than the threshold level, then absorption of technology is enhanced. The value of $\mathrm{SA}_{\mathrm{s}}$ is bound within the unit interval. It captures the notion that values of human development below a certain level entail minimal adoption of new technology, but beyond this level increases in human development facilitate its adoption. Note that the absorption capacity $\left(\mathrm{AC}_{\mathrm{t}}\right)$ and social acceptance $\left(\mathrm{SA}_{\mathrm{t}}\right)$ indexes are region 't' specific (i.e., generically, 't' can be destination and the origin).

In this paper, we reserve ' $s$ ' for the recipient whereas ' $r$ ' stands for the source region. It is to be noted that the definition for the spillover coefficient bears an additional subscript for source sector 'i' so that

$$
\gamma_{i j r s}\left(E_{i j r s}, \theta_{s}\right)=E_{i j r s}^{1-\theta_{s}}
$$

where $\gamma_{\mathrm{ijrs}}$ is the spillover coefficient between ' $\mathrm{i}$ ' in source ' $\mathrm{r}$ ' and ' $\mathrm{j}$ ' in destination ' $s$ ' and $\theta_{\mathrm{s}}$ is “capture parameter” or technology appropriation parameter (TAP) in's'. $\theta_{\mathrm{s}}$ is the product of the 
recipient-specific $\mathrm{AC}$-index $\mathrm{AC}_{\mathrm{s}}$ (where $0 \leq \mathrm{AC}_{\mathrm{s}} \leq 1$ ) and the institutional-structural congruence index $\mathrm{SC}_{\mathrm{rs}}$ (where $0 \leq \mathrm{SC}_{\mathrm{rs}} \leq 1$ ); it measures the efficiency with which the knowledge embodied in bilateral trade flows from source ' $r$ ' is captured by the recipients ' $s$ ' so that:

$$
\theta_{\mathrm{s}}=\mathrm{AC}_{\mathrm{s}} \cdot \mathrm{SA}_{\mathrm{s}} \cdot \mathrm{SC}_{\mathrm{rs}}
$$

Now, $\mathrm{SC}_{\mathrm{rs}}$ depends on the binary governance parameter $\left(\mathrm{GP}_{\mathrm{rs}}\right)$ and on the binary technological congruence parameter $\left(\mathrm{TC}_{\mathrm{rs}}\right)$. Thus, we can write

$$
\mathrm{SC}_{\mathrm{rs}}=\mathrm{GP}_{\mathrm{rs}} . \mathrm{TC}_{\mathrm{rs}}
$$

Therefore, with ' $r$ ' being a unique source it follows that for destination 's' at the macro ${ }^{13}$ level:

$$
\theta_{\mathrm{s}}=\mathrm{AC}_{\mathrm{s}} \cdot \mathrm{SA}_{\mathrm{s}} \mathrm{GP}_{\mathrm{rs}} \cdot \mathrm{TC}_{\mathrm{rs}}
$$

The actual productivity level from the potential streams of 'latest technology' depends on $\theta_{s} \in[0,1]$ with $\theta_{\mathrm{s}}=1$ implying full appropriation of foreign technology. For destination region ' $\mathrm{s}$ ', $\theta_{\mathrm{s}}$ and $\mathrm{E}_{\mathrm{rs}}$ jointly determine the value of the 'Spillover Coefficient' $\gamma_{s}\left(E_{r s}, \theta_{s}\right) \cdot \gamma_{s}($.$) has the properties that:$

$$
\gamma_{\mathrm{s}}(0)=0, \gamma_{\mathrm{s}}(1)=1, \gamma_{\mathrm{s}}^{\prime}=\left(1-\theta_{\mathrm{s}}\right) \mathrm{E}_{\mathrm{rs}}{ }^{-\theta_{\mathrm{s}}}>0, \gamma_{\mathrm{s}}^{\prime \prime}=-\theta_{\mathrm{s}}\left(1-\theta_{\mathrm{s}}\right) / \mathrm{E}_{\mathrm{rs}}{ }^{1+\theta \mathrm{s}}<0
$$

where primes indicate the first (') and the second ('") derivatives with respect to $\mathrm{E}_{\mathrm{rs}}$. More specifically,

$$
\gamma_{\mathrm{s}}\left(\mathrm{E}_{\mathrm{rs}}, \theta_{\mathrm{s}}\right)=\mathrm{E}_{\mathrm{rs}}^{1-\theta_{\mathrm{s}}}, 0 \leq \theta_{\mathrm{s}} \leq 1
$$

In the source region, the benefit of a technological change in a sector is reaped directly by that region's other sectors via the usage of domestic intermediates embodying advanced technology and indirectly via imported intermediates. Hence, the exogenous TFP improvement in ' $r$ ' endogenises TFP improvement in the receiving sectors via the domestic spillover effect so that:

$$
\mathrm{E}_{\mathrm{ijr}}=\mathrm{D}_{\mathrm{ijr}} / \mathrm{M}_{\mathrm{jr}} \quad(\mathrm{i} \neq \mathrm{j})
$$

where $\mathrm{D}_{\mathrm{ijr}}$ is the quantity of domestic tradeable commodity 'i' used by firms in sector ' $\mathrm{j}$ ' of source ' $\mathrm{r}$ ' and $\mathrm{M}_{\mathrm{jr}}$ is the domestic production of ' $\mathrm{j}$ ' in ' $\mathrm{r}$ '. When constructing on a binary scale by comparing the governance and the technological congruence parameters to their values in their own region ' $r$ ' , such 'binary values' are unity implying $\mathrm{SC}_{\mathbf{r r}}=1$. That is, a country is $100 \%$ congruent to its own structural parameters. Thus, we assume that the higher are AC and SA for a given constellation of TC and GP in ' $r$ ', the higher will be the domestic sectoral spillover, such that the spillover coefficient for source region is:

$$
\gamma_{i j r}\left(E_{i j r}, \theta_{r}\right)=E_{i j r}^{1-\alpha_{r}}
$$

where $\alpha_{\mathrm{r}} \in[0,1]$ is the human capital induced and social acceptance based capture-parameter for source ' $r$ '. $\theta_{\mathrm{r}}$ has one-to-one correspondence with $\alpha_{\mathrm{r}}$. The TFP transmission equation for the recipients can be written as

$$
\operatorname{ava}(\mathrm{j}, \mathrm{s})=E_{i j r s}^{1-\theta_{\mathrm{s}}} \cdot \operatorname{ava}(\mathrm{i}, \mathrm{r}) \quad(\mathrm{i} \neq \mathrm{j}, \mathrm{r} \neq \mathrm{s})
$$

\footnotetext{
${ }^{13}$ Keep in mind that here "macro” means common across all sectors and intermediate inputs in the client region.
} 
where ava (i, r) is the percentage change in TFP in source sector 'i' in region ' $r$ '.

\section{B. A Stylized Mechanism for Income Inequality Reduction via Spillover}

\section{Technology Spillover and Initial Income Inequality}

There is evidence that whilst income inequalities have been relatively stable inter-temporally within countries, between nations there have been substantial international variations in inequality of income as measured by Gini coefficients (Squire and Zou 1999; Deininger and Squire 1998). Squire and Zou (1999) have shown that for 42 out of 49 countries in their study the intertemporal changes of Gini coefficient are relatively modest. The larger variations across nations are explained in terms of structural determinants such as education, political feasibility, governance, and demographic factors.

As mentioned in Section III, the capture parameter $\theta$ is an amalgam of AC, SA, TC and GP. The Gini index (G) lies in the closed interval [0,1], 0 indicating complete equality and 1 indicating extreme inequality. In conformity with the empirical regression analysis in Section II.B where trade reduces inequality, we specify a stylized mechanism for such a negative effect linking trade, technology spillover, and trade-induced productivity, with inequality. ${ }^{14}$ In our formulation, we consider a Human Development Index (HDI) as a proxy for social acceptance of foreign technology and hence, it embraces a wider perspective of poverty. ${ }^{15}$

Most previous studies fail to consider the geographical dispersion of productivity spillovers and their repercussions on inequality convergence or divergence. They trace the roots of the causality between a trade orientation index (i.e., a measure of openness derived from exports plus imports normalized by a country's GDP), its Gini coefficient of income inequality and its rate of economic growth. However, in our framework the role of the Capture parameter is crucial. Thus, higher trade-mediated technology flows and induced productivity escalation depend on higher values of the spillover coefficient and $\theta$, while $\theta$-values depend on the constellation of AC, SS, TC and GP. Higher $\theta$ means lower Gini values and vice versa. Therefore, trade can facilitate inequality convergence if these factors are right in the sense that when perfect capture and spillover is possible [i.e., $\theta=1$ ], then inequality is non-existent [ $\mathrm{G}=0$ ] whereas with almost no spillover capture [i.e., $\theta=0$ ], inequality is high with extreme poverty $[G=1]$. Now, starting with an existing level of income inequality, one can reduce inequality and hence, incidence of poverty.

Starting with a given initial value of the Gini index (G) measuring the existing level of income inequality within a region, it is postulated that the higher is the value of technology capture $(\theta)$ induced by spillover coefficient [i.e., $\gamma_{s}\left(E_{r s}, \theta_{s}\right)$ defined in equations 3 and 5 above], the lower will be the degree of income dispersion, implying a more egalitarian distribution, which will be reflected in a lower value of the Gini index. Conversely, the lower are the realized values of $\gamma_{s}\left(E_{r s}, \theta_{s}\right)$, the greater will be the extent of the income gap due to lower technology appropriation resulting in higher income inequality and hence, the magnification of Gini values. Thus, from a policy perspective, a nation with an existing level of inequality or poverty could bypass the 'inequality trap' and achieve growth if there

\footnotetext{
${ }^{14}$ One could consider Gini distribution of inequality in labor productivity. However, here we consider effect of productivity spillover on income inequality and hence, such issue is not considered.

${ }^{15}$ Human Poverty Index is an alternate measure of income poverty and it is deprivational index (see Anand and Sen 1997). It includes three components viz., survival deprivation, educational and knowledge deprivation, and economic deprivation.
} 
were an appropriate constellation of factors like literacy, education, social capital, governance, and infrastructure. These factors determine the extent of technology capture $(\theta)$. Thus, trade and technology can have a dampening effect on Gini coefficients-growth raises the initial income level and subsequently promotes higher growth. In fact, Hertel and Reimer (2004), and Dollar and Kraay (2002) cogently analyze a different genre of models where, by large, trade liberalization and growth have a positive impact on poverty reduction. In a study of recent vintage, Cline (2004) presents country-specific poverty elasticities with respect to trade and aggregate income growth - the values ranging between 1.0 and 3.5. By incorporating a measure of pure productivity effect with respect to trade reform, he estimates 650 million people overall are able to escape from poverty. In another study by World Bank Development Prospects Group (DPG 2004), with a poverty elasticity of 2.0, the estimated reduction in poverty is in the magnitude of 320 million persons. However, both these studies confirm the hypothesis that trade and associated productivity benefits have a potential poverty-reduction effect. With this in mind, we formulate a specification for such conjugated growthenhancing, poverty reducing mechanism.

Let $\mathrm{G}_{\text {initial }}=$ existing initial level of income inequality;

$\mathrm{G}_{\text {convert }}=$ transformed magnitude of $\mathrm{G}_{\text {initial }}$ owing to spillover effect via capture-parameter.

We specify the functional relation between $\mathrm{G}_{\text {initial }}$ and $\mathrm{G}_{\text {convert }}$ generally such that,

$$
\mathrm{G}_{\text {convert }}=\mathrm{F}\left(\mathrm{G}_{\text {initial }}, \theta\right)
$$

where $F\left(G_{\text {initial }}, 0\right) \rightarrow 1$ (implying high inequality) and $F\left(G_{\text {initial }}, 1\right) \rightarrow 0$ (implying low inequality or more egalitarian distribution). The ' $F$ ' function thus binds initial Gini values into the closed interval $[0,1]$ and transforms the existing initial Gini-index value so that for an existing level of inequality if there is some technological spillover or innovation-appropriation, the higher capture reduces the existing inequality (reflected into a relatively lower inequality index).

In particular, we postulate an inverse logistic relationship ${ }^{16}$ between $G_{\text {initial }} \in[0,1]$ and $\theta \in[0,1]$ such that when $\theta$ rises from 0 to $1, G_{\text {initial }}$ falls from 1 to 0 . Therefore, we write, for any region 's', generically:

$$
\mathbf{G}_{\text {convert(s) }}=\mathbf{G}_{\text {initial }(s)} * \frac{\mathbf{e}^{-\mathbf{g} \gamma(\mathrm{s})} \cdot \eta(\mathbf{s})}{\mathbf{Y}_{\text {initial }}(\mathbf{s}) . \mathrm{e}^{-\mathbf{g} \gamma(\mathrm{s})}+1}
$$

where

$\mathrm{g}$ = average proportional rate of decrease of Gini coefficient due to growth in trade dependency ratio (trade as a percentage of GDP);

$\gamma(\mathrm{s})=$ regional spillover coefficient parameter;

$\eta(s)=$ elasticity of poverty with respect to trade liberalization;

\footnotetext{
${ }^{16}$ One could have an inverse linear specification where $G_{\text {convert }}=1-F\left(G_{\text {initial }}, \theta\right)$. However, this is not strong specification. Alternatively, another nonlinear specification is Cobb-Douglas: $\mathrm{G}_{\text {convert }}=\mathrm{G}_{\text {initial }}{ }^{\gamma(\mathrm{Ers}, \theta \mathrm{s})]}$ where no spillover implying $\gamma_{\mathrm{s}}=0$ means $\mathrm{G}_{\text {convert }}=1$ (that is, perfect inequality) and $\gamma_{\mathrm{s}}=1$ implies $\mathrm{G}_{\text {convert }}=\mathrm{G}_{\text {initial }}$ (that is, initial inequality prevails) without any magnification of inequality. Thus, it is less robust in terms of effect of spillover on inequality convergence.
} 
$Y_{\text {initial }}(\mathrm{s})=$ initial poverty threshold income level (relative) for each 's'. It could be normalized with respect to the country/region with highest value; thus, it hovers around unity.

The scalar product of spillover coefficient $(\gamma)$, growth elasticity (g) and poverty elasticity $(\eta)$ is called the 'Poverty Reduction on GRowth and Embodied Spillover Synergy (PROGRESS)' parameter.

Given $\gamma_{\mathrm{s}}^{\prime}=\left(1-\theta_{\mathrm{s}}\right) \mathrm{E}_{\mathrm{rs}}{ }^{-\theta_{\mathrm{s}}}>0$, we can use equation (11) to infer that

$$
\frac{\partial \mathbf{G}_{\text {convert }}(\mathbf{s})}{\partial \theta_{\mathbf{s}}}=\left[\frac{\mathbf{G i n i t i a l}_{(\mathbf{s})} * \eta(\mathbf{s})}{\mathbf{Y}_{\text {initial }}(\mathbf{s}) \cdot \mathbf{e}^{-\mathbf{g} /(\mathbf{s})}+1}\right] \times(-\mathbf{g}) \mathbf{e}^{-\mathbf{g} \gamma(\mathbf{s})} \times \gamma^{\prime}(\mathbf{s})<0
$$

Under alternative specification where all the component 'PROGRESS' parameters enter exponentially, then

$$
\text { Gconvert }(\mathbf{r})=\operatorname{Ginitial}(\mathbf{r}) \times \frac{\mathbf{e}^{-\mathbf{g} \gamma(\mathbf{r}) \cdot \eta(\mathbf{r})}}{\mathbf{Y}_{\text {initial }(\mathbf{r}) \cdot \mathbf{e}^{-\mathbf{g} \gamma(\mathbf{r}) \cdot \eta(\mathbf{r})}+1}}
$$

In both cases, the results do not differ qualitatively with the exception that in the multiplicative case in equation (20), the values are sensitive to the poverty elasticity. With high (>2) values of the poverty, the values of converted Gini explode. However, from the specifications above and the sign of the derivative [i.e., $\frac{\partial \mathbf{G}_{\text {convert }}(\mathbf{s})}{\partial \theta_{\mathbf{s}}}<0$ ], we can infer that a higher trade to GDP ratio, via ' $g$ ', affects average growth in income positively via embodied spillover induced TFP: hence, income inequality is reduced. This, in turn, causes a decline in poverty the size of which is determined by the magnitude of the poverty elasticity (i.e., $\eta(s)$ ). From our stylized facts (section II), the value for ' $\mathrm{g}$ ' is taken as $0.2 \%$-also supported by findings of Chakrabarti (2000). Ideally speaking, $\eta(s)$ should vary from region to region, and depending upon these magnitudes, the dampening effect of trade-mediated growth will vary regionally. In our implementation, however, following Hertel (2004) and the World Bank Development Prospects Group's Global Economic Prospects (2004), we set values for $\eta(r)$ uniformly at 2.0. According to Cline (2004), a 1 percentage point increase in economic growth generated by an increase in exports leads on average to a $2 \%$ reduction in poverty.

From (20) and (21), when $\gamma \rightarrow \infty, 1 / \mathbf{e}^{\infty} \rightarrow 0$ and hence, $\mathrm{G}_{\text {convert }} \rightarrow 0$; i.e., with infinitely large spillover capture, income inequality vanishes asymptotically, phasing to egalitarian income distribution. On the contrary, when $\gamma \rightarrow 0, \mathrm{e}^{0} \rightarrow 1$ and with $\eta \in[2,2.5], \mathrm{G}_{\text {convert }} \rightarrow \mathrm{G}_{\text {initial }}$; i.e., with null spillover effect, the initial level of inequality persists or even magnified. This is because in the absence of any spillover benefits above threshold level of income, there is no technology capture and hence, no vehicle for poverty alleviation via trade. This leads to capability failure and functional failure so that there is dampening effect on impact of technology transmission. With technology capture and transmission, however, more of the populace will cross over a poverty and income threshold for a given percentage increase in productivity. It is pertinent to note that growth with its dampening effect on inequality of income can have poverty alleviating impact.

\section{Gap in Gini Indexes and Technology Capture: A Formal Linkage}

As there are causal linkages between productivity and domestic investment in human capital, social capital, technology and governance, it is pertinent to investigate if the trade inflows in conjunction with these factors enable the countries to achieve convergence in inequality by closing the gap in 
poverty. A poverty gap is another signaling indicator of an income inequality gap. ${ }^{17}$ According to Chen and Ravallion (2004), "poverty gap [measures] the mean distance below the poverty line as a proportion of the poverty line." Non-poor or rich is assumed to have a zero poverty gap and hence, this measure reflects inequality among the poor. Following Bourguignon (2004), for small mean income changes and changes in distribution of relative income, change in poverty is a function of growth in mean income and change in relative income distribution. Thus, changes in growth and inequality in (relative) distribution generate changes in poverty depending on initial inequality.

In our model, we postulate that the higher is the value of the capture parameter, the higher will be the rate of technology absorption. Thus, the initial poverty gap in a region ' $r$ ', being dependent on technology capture, is reduced by the spillover; given transformed Gini indexes $\left(\mathrm{G}_{\text {convert }}\right)$, the higher is the $\theta$ value, the lower is the gap between the Gini's for inequality and for mean income.

Let $\mathrm{PG}_{\mathrm{r}}=$ poverty gap in any region ' $\mathrm{r}$ ';

$\mathrm{G}_{\text {convert }}(\mathrm{r})=$ transformed Gini values due to spillover effect (as before from equation (20));

$\mu(\mathbf{r})=$ mean absolute income of a nation ' $r$ ' as ratio of income to poverty line of $\$ 1.08$ a day (see Chen and Ravallion 2004).

Thus, for any $\mathrm{r}$, we write: $\mathrm{PG}_{\mathrm{r}}=\mathrm{G}_{\text {convert }}(\mathrm{r})-\mu(\mathrm{r}) \times \ln \left(\theta_{\mathrm{r}}\right)$

Thus, given $\mathrm{G}_{\text {convert }}(\mathrm{r})$ and $\mu(\mathrm{r}), \partial(\mathbf{P G}) / \partial \theta_{\mathbf{r}}=-\frac{\mu_{\mathbf{r}}}{\theta_{\mathbf{r}}}$, where $\theta, \mu>0$. This means that for given income $\mu(r)$, when the capture parameter augments the spillover, the poverty gap diminishes. Using equations (12) and (14), for the binary relation between two regions-source ' $r$ ' and destinations ' $\mathrm{s}$ ' - the Gap in Gini for any destination region ' $\mathrm{s}$ ' when ' $r$ ' is unique (' $r$ ' being the unique source region, we do not need an 'r' subscripted variable on the left) is,

$$
\mathrm{PG}(\mathrm{s})=\mathrm{G}_{\text {convert }}(\mathrm{r})-\mu(\mathrm{s}) \times \ln \left(\theta_{\mathrm{r}} / \theta_{\mathrm{rs}}\right)
$$

Hence, using (21), given $\frac{\partial \mathbf{G}_{\text {convert }}(\mathbf{s})}{\partial \theta_{\mathbf{s}}}<0$, we write also $\partial$ (PGs) $_{\partial \theta_{\mathbf{r s}}}<0$.

The upshot is that a higher capture parameter translates into higher technological spillover; also, per capita income of recipient regions rise due to induced productivity improvement. This, in turn, translates into reduced income and productivity gaps. In what follows, we implement the model.

\section{Database, Methodology and Framework}

\section{A. Database}

Multi-regional, multi-sectoral computable general equilibrium (CGE) models score over other analytical tools for better understanding of global trade policy issues (see Flam 1992, De Rosa 1998, Hertel 1997). CGE models are also used in analyses linking trade and poverty. Cline (2004), Hertel (2004) are examples of such applications. In particular, the Global Trade Analysis Project's (GTAP)

\footnotetext{
${ }^{17}$ Chen and Ravallion (2004, World Bank Research Observer) defines Poverty Gap, PG $=[1-$ ratio of mean income of the poor to the poverty line] $\times$ Head count ratio.
} 
Version 5.4 (beta release) global database and the modified CGE trade model is used for undertaking the research (see Hertel ed. 1997; Dimaranan and McDougall, May 2002). ${ }^{18}$ The model is non-linear with detailed sectoral and regional specifications based on micro foundations. Version 5.4 of the GTAP database disaggregates the world economy into 78 regions (both single and composite) and 57 sectors. This global database describes bilateral trade flows, production, consumption and intermediate input flows of commodities and services across sectors and regions. A reduced dimension $14 \times 12$ aggregation of the database is used to calibrate the model. Choice of regional dimension is motivated by our primary emphasis on the trade-growth-poverty nexus. In terms of the sectoral aggregation, we consider twelve commodity types.

Table 5 presents the regional and sectoral aggregations. High-technology products are supposedly intensive in sophisticated technology and trade in such products is a primary conduit for technological spillover across borders. Commodities are produced using both primary and intermediate factors of production. Following Armington's (1969) specification, products are differentiated by geographical region of origin. The GEMPACK software suite developed at the Centre of Policy Studies, Monash University, Melbourne, Australia is used to conduct simulations (Harrison and Pearson 1994 and 1996).

\section{Table 5 - Sectoral and Regional Aggregations used for the Implementation}

\begin{tabular}{ll}
\hline Version 5.4 Sectors with Identifier & Version 5.4 Regions with Identifier \\
\hline 1. Pdr [Paddy, Rice] & 1.USA [United States] \\
2. Wht [Wheat] & 2. CAN [Canada] \\
3. Gro [Grains] & 3. Ind [India] \\
4. LMNFCS [Light manufacturing] & 4. Chn [China] \\
5. HMNFCS [Heavy manufacturing] & 5. Jpn [Japan] \\
6. HITECH [High Technology Products] & 6. Sam [Latin American Countries] \\
7. V_F [ Vegetable, Fruits, etc.] & 7. MERCOSUR [Argentina, Brazil, Uruguay, Paraguay] \\
8. Osd [Oilseeds] & 8. Sea [South East Asia] \\
9. Extract [Natural Resources] & 9. Osa [Other South Asia] \\
\hline 10. Food [Food and Agriculture] & 10. Slk [Sri Lanka] \\
\hline 11. TexClt [Textile and Clothing] & 11. HTW [Hong Kong and Taiwan] \\
\hline 12. SVC [Services and activities, NES] & 12. Bgd [Bangladesh] \\
\hline & 13. EUFTA [European Union] \\
\hline & 14. Rest of the World [ROW]
\end{tabular}

Source: Author's aggregation based on GTAP V5.4 database. Details of sectoral composition are not reported for parsimony.

\section{B. Parameters Settings}

Our augmented theoretical model incorporates four sets of parameters in addition to the standard GTAP model parameters. These are the skill-induced AC index, governance parameter GP, social acceptance parameter $S A$, and technological proximity parameter TC. For the absorption capacity parameter, we calculate the regional ratios of skilled to unskilled labor payment shares and use these as proxying $\mathrm{AC}$. Calculation shows that the values of $\alpha_{\mathrm{r}}$ proxying $\mathrm{AC}_{\mathrm{USA}}$ and $\mathrm{AC}_{\mathrm{HTw}}$ are the highest

${ }^{18}$ GTAP 6 is the latest release of the database based solely on the beta release of Version 5.4 database. However, Version 6 extends the beta release to more regions with same number of sectors and those regions are not subject of analysis in the present research and hence, it does not undermine our purpose. 
of all the regions. Calculated $\mathrm{AC}$-values are such that $\mathrm{AC}_{\text {USA }}>\mathrm{AC}_{\mathrm{HTW}}>\mathrm{AC}_{\mathrm{EUFTA}}>\mathrm{AC}_{\mathrm{JAPAN}}>\mathrm{AC}_{\text {MERCOSUR }}>\mathrm{AC}_{\mathrm{SAM}}>\mathrm{AC}_{\mathrm{CAN}}>\mathrm{AC}_{\mathrm{CHINA}}>\mathrm{AC}_{\text {INDIA }}>\mathrm{AC}_{\text {SOUTHASIA }}$. However, for composite regions such as Hong Kong-Taiwan, South East Asia or South America, the figures are high. For example, Canada trails behind EU and MERCOSUR whereas within the same group the differences are small and show similar intensity implying that they have more or less similar patterns of skill intensity. Thus, from the AC-index it is obvious that the developing regions in geographical proximity, in general, have low skill intensities compared to the US but amongst themselves they exhibit broadly similar patterns.

Regarding the binary structural congruence parameter (SC), we consider two constituents: TC and GP. For GP, we proceed in several steps: (i) we use the World Bank's comprehensive data on six dimensional governance indicator made available by Kauffman et al. (2003) and Kauffman (2004). ${ }^{19}$ These values at the disaggregated level are bounded between -2.5 and +2.5 ; (ii) on the basis of these disaggregated observations at the regional level for each category, we construct a simple average composite governance indicator for each GTAP region as representative for overall institutionalstructural features. Typically, the six aspects, 'by virtue of inherent commonality', are interrelated. Thus, the composite indicator (a simple arithmetic average of the estimated scores on each separate aspect) is a reasonable proxy for the overall attribute of governance. For composite regions, we calculate such aggregate values by mapping the component GTAP regions with regions in the dataset of Kauffman et al. (2003). Having constructed such individual country/regional indexes, we transform them via Equation (8) to find binary indexes of the concerned regions with the unique source. We consider the absolute magnitude of the indexes as we make a relative scaling for binary comparison with respect to USA as the benchmark. The values are bounded between '0' (extremely low degree of governance) and unity (i.e., like the value for USA vis-à-vis Canada and EU with almost perfect governance). Based on these findings, we infer that USA, EU, Japan and Canada are more institutionally homogeneous as opposed to other developing countries. From our calculation, as expected, we see that for MERCOSUR and the other bloc of Latin American countries, the governance indicator is quite low. However, for South Asia and East Asia, these values are not as low. In the case of India and Sri Lanka as compared to Bangladesh and other South Asian countries, the magnitude of the GP parameter is higher- 0.65 for India and 0.69 for Sri Lanka. ${ }^{20}$

In the case of China, the value of this binary parameter is lower (0.32) compared to the Hong KongTaiwan composite region (0.74). The lower value for China might be attributed to laxity in effectiveness of government in protecting property rights and in control of corruption.

In the literature the most widely used comprehensive proxy corresponding to the technology adjacency parameter (TC) is either the Technology Achievement Index (TAI) or, R\&D expenditure as

\footnotetext{
${ }^{19}$ These indicators for perceived institutional quality are: Voice and accountability, Political stability, Government effectiveness, Regulatory quality, Rule of law, and Control of corruption. Although basic calculations and data sources are presented, the values of such parameters for AC, SA, TC and GP are not reported here for want of space.
}

${ }^{20}$ By calculating the composite values of GP indices from its estimates of score of each of the 6 components, we get figures for Bangladesh and Sri Lanka as more negative compared to that in India. This implies better governance in India compared to those South Asian nations. But, taking absolute magnitude gives erroneous perceptions about this parameter. To avoid this inconsistency, we make adjustments by calculating regional averages of 6 indices (6.49) and then, take the difference of each of the countries GP values to compute the relative difference/distance from regional average of South Asia. This gives consistent measure of GP values of South Asian nations. 
percentage of GDP. It is assumed that the higher is the value of TAI or R\&D, the higher is the degree of technological proximity and the greater is the scope for integration facilitating knowledge capture. The values of TAI are taken from Human Development Report (2001) and R\&D figures are taken from Human Development Report (2003). We take TAI values for all the regions except for those regions where such values are missing; for those we assign, in conformity with the same pattern of values of R\&D expenditure share in GDP, the share values of hi- and medium- technology exports as indicators of technological achievement. Typically, via Equation (9), USA, Canada, EU and Japan have higher binary values of almost unity i.e., they are (almost) technologically similar to each other.

For SA (via equation 10), we consider a human development index (Human Development Report, 2003) - a measure of standard of living and quality of life. Thus, the higher is the quality of life and living standard of a nation the higher is the degree of acceptance of a new technology and the lower is the extent of poverty. For the threshold value, we take East and South East Asia's composite human development index. ${ }^{21}$ Assuming that the higher is such value, the higher is the scope of socioinstitutional homogeneity translating into higher extent of knowledge capture, we assign perfect acceptance level for USA, Canada, Hong Kong, Japan and EU.

The model is solved using the customized Windows program Gempack. ${ }^{22}$ In what follows, we describe the simulation design and policy experiments.

\section{Simulation Design, Scenarios AND RESUlts}

For our analysis of the technology, trade and inequality nexus, among other regions we focus on two emerging economies with huge populations living under poverty; namely, India and China. The 'roaring tiger' India and the 'awakening dragon' China are the two upcoming regions where trade reforms and globalization measures have spurred voluminous trade and consequential rises in income levels. These two countries contain more than $33 \%$ of the world's population (i.e., totally 2.4 billion out of global 6.2 billion). According to World Bank reports the headcount fraction of population in poverty (income [or consumption?] less than $\$ 2$ per day) is $53.7 \%$ for China and $86.2 \%$ for India (Cline, 2004). Of late, considerable research has been undertaken to investigate the income distributional consequences of such trade openness. According to Cline (2004), the estimated poverty rates for India and China are 48.4 and $39.2 \%$ respectively.

Implications of policy reforms on reducing inequality and poverty are important for these two countries. Here, we explore the possibility (or impossibility) of reduction in income poverty in these two major economic heavyweights via trade with major trading partners like the US. Thus, we consider a scenario where the scope of a hub-and-spokes three player configuration in global trade between USA vis-à-vis India and China is an important factor. The emergence of India as a major outsourcing spoke of the US and China as another sub-spoke has drawn attention to the povertyreducing impact of trade.

\footnotetext{
${ }^{21}$ The reason behind choosing East and South East Asia as borderline case of threshold level is that these regions, over last two decades have embarked on a path of human resource-led development path and achieved remarkably high growth cycles. This miraculous performance sets them as a reference region (see East Asian Miracle, World Bank 1993).

${ }^{22}$ This is developed by Ken R. Pearson and colleagues at the Centre of Policy Studies/IMPACT, Monash University, Australia based on GEMPACK software suite. See Harrison and Pearson (1996) for GEMPACK simulation software.
} 
In what follows, we describe the policy experiments. We consider two generic types of shocks: viz., [1] technology shocks related to TFP augmentation in a [the?] high-technology sector in USA transmitted to other nations; and [2] trade policy shocks related to a trade liberalization episode under Hub-and-Spokes (HAS) FTA configurations between USA vis-à-vis India and China.

\section{A. Technology Spillover and Inequality Scenario: Pure Productivity Shock}

In this scenario, we consider an exogenous total factor productivity augmentation in the Hitechnology sector in the source region (USA) that is transmitted to client regions. To the best of our knowledge, amongst recent studies only Keller $(1997,1999)$ calculated a TFP index by industry for 8 OECD countries. We match Keller's (1999) ISIC [revision 2] sectors with the GSC1 sectors in our current implementation. From the figures, it is evident that the industries included in the hi-tech and heavy manufacturing clusters in the USA experienced rapid technological change and hence, relatively high average annual TFP growth during 1970-91 - around 3.4\% per annum is the average growth rate in such sectors. We consider the US hi-tech sector as the source of innovation. According to Keller (1999), the average annual growth in multifactor productivity in the composite hi-tech sector was $3.2 \%$ during 1970-1991.

We use a linear extrapolation method to extrapolate growth rates over 6 years encompassing the simulated period. Thus, the extrapolated growth rate of 4 (approximation to 3.86) per cent per annum is used as the TFP shock ${ }^{23}$. In particular, we shock the Hicks-Neutral technological coefficient in the hi-tech sector of the USA by $4 \%$. The closure is the standard GTAP macroeconomic closure (see Hertel 1997; McDougall 2003, GTAP version 6.2). We consider two major spokes, namely, India and China, and other regions as well.

\section{Analysis of Results under Pure TFP Shock}

In this section, we consider macroeconomic repercussions following TFP escalation per se. Because technological change is more predominant in the manufacturing sectors, we confine our discussion mainly to hi-tech, heavy manufacturing and light manufacturing for the regions US, Canada, China, India, other Asian countries and MERCOSUR. ${ }^{24}$ After the TFP improvement in hi-tech in the US and the associated endogenous TFP changes in all other sectors (both domestically and abroad), the economy-wide indexes of TFP register an improvement in all the regions. However, the magnitude of the index differs markedly across the regions (row 1, Table 6). The US, being the source of innovation, experiences the highest overall technological progress; more importantly, amongst the recipients, Canada, EU and South America (including Mexico under NAFTA) receive higher doses of technology transmission than the other regions. Being neutral in nature, the TFP change translates into an equivalent increase in real GDP at factor cost in the regions. However, the discrepancies in TFP growth performances across regions can be attributed to differences in technology capture depending on the magnitudes of their capture parameters and their constituents given by sets of equations (8) to (14).

\footnotetext{
${ }^{23}$ According to Keller $(1999,2001)$ the rate of growth of R\&D stock in USA is $7.4 \%$ of which $90 \%$ is originating in manufacturing comprising hi-tech and heavy manufacturing. That is, the growth of $\mathrm{R} \& \mathrm{D}$ in manufactures especially in two sectors heavy manufacturing and hi-tech. is $0.90 \times 7.4 \%=6.4 \%$ (approximately). Simple average of the TFP indexes in these 2 sectors is also $3.2 \%$

${ }^{24}$ Due to limitations of space, we report only selected most important ones.
} 
Table 6. Simulated Regional Effects of 4\% TFP Shock in the Hi-tech Sector in the US on Selected Macroeconomic Variables (percent changes)

\begin{tabular}{|c|c|c|c|c|c|c|c|c|c|}
\hline Percentage change in: & US & Canada & $\mathrm{EU}$ & China & $\begin{array}{l}\text { South } \\
\text { America }\end{array}$ & India & $\begin{array}{l}\text { MERCOS } \\
\text { UR }\end{array}$ & $\begin{array}{l}\text { Bangla- } \\
\text { desh }\end{array}$ & $\begin{array}{l}\text { Sri } \\
\text { Lanka }\end{array}$ \\
\hline 1. Region-wide index of TFP growth & 3.6 & 2.2 & 0.76 & 0.11 & 1.65 & 0.10 & 0.30 & 0.12 & 0.16 \\
\hline 2. Real GDP at Factor Cost & 3.6 & 2.2 & 0.76 & 0.11 & 1.65 & 0.10 & 0.30 & 0.12 & 0.16 \\
\hline
\end{tabular}

Source: Simulations by the authors.

As is evident from Table 7, the capture of transmitted technology depends on the magnitudes of the economy-wide and sectoral embodiment indexes and spillover coefficients in the destinations vis-àvis USA.

Table 7. Values of Economy-Wide Embodiment-Indexes, Spillover Coefficients, Parameters for Governance, Social Acceptance, Capture and Congruence ${ }^{(a)}$

\begin{tabular}{|l|l|l|l|l|l|l|l|l|}
\hline $\begin{array}{l}\text { GTAP } \\
\text { Regions }\end{array}$ & $\begin{array}{l}\text { Embodiment } \\
\text { Index } \\
(1)\end{array}$ & $\begin{array}{l}\text { Spillover } \\
\text { Coefficient } \\
(2)\end{array}$ & $\begin{array}{l}\text { Capture- } \\
\text { Parameter } \\
\left(\gamma_{\mathrm{irs}} / \mathrm{E}_{\mathrm{ir}}\right)\end{array}$ & $\begin{array}{l}\left.\mathrm{AC}_{\mathrm{r}}\right) \\
(3)\end{array}$ & $\begin{array}{l}\mathrm{GP}_{\mathrm{rs}} \\
(4)\end{array}$ & $\mathrm{TC}_{\mathrm{rs}}$ & $\begin{array}{l}\mathrm{SC}_{\mathrm{rs}}= \\
\mathrm{TC}_{\mathrm{rs}} \times \mathrm{GP}_{\mathrm{rs}}\end{array}$ & $\mathrm{SA}_{\mathrm{s}}$ \\
\hline 1. USA & 0.62 & 0.82 & 0.71 & 0.71 & 1.00 & 1.00 & 1.00 & 1.00 \\
\hline 2. Canada & 0.38 & 0.51 & 0.32 & 0.40 & 1.00 & 0.80 & 0.80 & 1.00 \\
\hline 3. China & 0.02 & 0.03 & 0.03 & 0.23 & 0.32 & 0.41 & 0.13 & 0.95 \\
\hline 4. India & 0.02 & 0.03 & 0.03 & 0.21 & 0.65 & 0.27 & 0.18 & 0.74 \\
\hline $\begin{array}{l}\text { 5. } \\
\text { MERCOSUR }\end{array}$ & 0.05 & 0.06 & 0.08 & 0.44 & 0.46 & 0.46 & 0.21 & 0.90 \\
\hline $\begin{array}{l}\text { 6. South } \\
\text { America }\end{array}$ & 0.38 & 0.38 & 0.01 & 0.40 & 0.04 & 0.43 & 0.02 & 0.90 \\
\hline 7. Bangladesh & 0.03 & 0.02 & 0.002 & 0.28 & 0.22 & 0.05 & 0.01 & 0.62 \\
\hline 8. Sri Lanka & 0.03 & 0.03 & 0.05 & 0.27 & 0.69 & 0.28 & 0.19 & 0.90 \\
\hline 9. EU & 0.04 & 0.18 & 0.47 & 0.67 & 1.00 & 0.69 & 0.69 & 1.00 \\
\hline 10. HTW & 0.09 & 0.20 & 0.33 & 0.71 & 0.74 & 0.62 & 0.46 & 0.99 \\
\hline 11. Japan & 0.02 & 0.10 & 0.48 & 0.62 & 0.82 & 0.95 & 0.78 & 1.00 \\
\hline
\end{tabular}

Source: Authors' simulations; (a) Values shown relate to the base period pre-shock levels.

The aggregate spillover index gives us an average overall magnitude of technology appropriated by all user sectors in the source as well as client regions via intermediate inputs. Table 7 shows that the aggregate embodiment index in the USA $\left[E_{i r}\right]$ is higher than those in the destinations $\left[E_{\text {irs }}(s \neq r)\right]-$ compare figures in column 2. Since the capture-parameter $\left(\theta_{r}\right)$ in USA is higher than $\theta_{s}$ in all the regions (column 4), from Equations (11) and (14) it is clear that USA reaps the maximum spillover $\left(\gamma_{i r}\right)$ (column 3). Looking at congruency parameter (column 8), we infer that much of the spillover capture can be attributed to the 'right' constellations of appropriate socio-institutional factors (i.e., GP, TC and SA) aided by the absorption index (column 5).

The higher value of those parameters (and hence of the capture parameter $\left[\theta_{r}\right]$ ) magnifies the value of the embodiment index, thus enabling Canada, South America and the EU to record a much higher rates of TFP improvement than other regions in South Asia and China. Higher volumes of trade flows 
from USA under NAFTA inflate aggregate embodiment indexes in Canada and South America (see column 2). For EU and Japan, the magnitude of the technology appropriation parameter is high. Despite MERCOSUR having a higher $\theta_{\mathrm{r}}$ than South America, a higher embodiment index and spillover coefficient in South America translate into relatively higher TFP and welfare gains there (Table 8). India, Sri Lanka, China and the other South Asian regions are relatively backward in capture. Lower TC and SC values lead to lower capture by countries like Bangladesh. However, higher AC and trade-embodiment facilitates technology-led growth there.

Table 8. Simulated Regional Effects on Aggregate Performance

\begin{tabular}{lllllllll}
\hline Change in: & USA & Canada & China & India & \multicolumn{2}{c}{ MERCOS } & $\begin{array}{l}\text { South } \\
\text { America desh }\end{array}$ & \multicolumn{2}{c}{ Bangla- Sri } \\
& & & & & UR & Aank \\
\hline 1. Terms-of-trade & 0.29 & 0.13 & 0.03 & -0.24 & -0.42 & 0.12 & -0.08 & 0.24 \\
2. Aggregate export price index & -1.26 & -1.27 & -1.55 & -1.79 & -2.00 & -1.34 & -1.66 & -1.35 \\
3. Aggregate import price index & -1.54 & -1.39 & -1.58 & -1.55 & -1.57 & -1.46 & -1.59 & -1.58 \\
4. Real value of exports & 0.53 & 1.75 & 1.36 & 2.32 & 3.11 & 1.58 & 2.56 & 0.84 \\
5. Real value of imports & 4.17 & 2.53 & 0.15 & -0.58 & -0.86 & 1.85 & 0.13 & 0.32 \\
6. Regional Household Income & 4.01 & 2.50 & 0.15 & 0.07 & 0.22 & 1.91 & 0.12 & 0.31 \\
7. Change in trade balance (in US \$ & & & + & + & + & - & & + \\
million) & -41848.0 & -1317.3 & 2572.9 & 1272.8 & 4066.7 & 352.7 & +150.1 & 43.23 \\
8. Welfare (EV) (in million US \$) & 289291.2 & 14191.3 & 1149.5 & 244.68 & 2226.4 & 14169.8 & 48.5 & 42.5 \\
\hline
\end{tabular}

Source: Simulation by author. Note: First 6 rows report results in Percentage changes. Reported welfare and trade balance changes in rows 7 and 8 are in levels (\$ million).

In the case of India, China, Bangladesh and Sri Lanka the growth in TFP induced by spillover is of lower order of magnitude. This is owing to the fact that these countries, unlike those in NAFTA and EUFTA and Latin American regions, relatively speaking, do not have much trade-mediated spillover capture from USA. Moreover, due to lower values of trade-embodiment indexes the magnitude of spillover coefficient is much lower for these South Asian nations as compared to EU, Canada and South America. In addition, the values of the capture parameter are relatively lower in these countries compared to Japan, Canada, EU and Hong Kong and Taiwan (see column 4). These lower values translate into lower regional TFP indexes for India, China and other South and East Asian regions in our model. From Column 8, comparing the values we can infer that these regions are socioinstitutionally much less congruent to the US and hence the transmitted benefits are not captured in its fullest potential as is found in case of institutionally more similar regions like Canada or EU. Note that the ordering of the spillover coefficient in column 3 of Table 7 matches the ordering of the real GDP in row 2 of Table 6.

Regarding the post-simulation trade scenario, Table 8 shows that the aggregate volume of exports increases in the principal beneficiaries of TFP changes. The real value of imports increases for all regions except India and MERCOSUR. Because the changes in price relativities across regions induce changes in regional terms-of-trade (TOT), the pattern of inter-regional competition is disturbed. The preceding discussion shows that the TFP shock erodes the competitiveness of China, India, Bangladesh and Mercosur (due to lower capture) whereas USA, Canada and Mexico become more competitive. The countries and regions (namely, MERCOSUR, India, and Bangladesh) for which export prices have fallen more than the aggregate import prices, have been able to register positive changes in their trade balance. This is due to the technology transmission and its effective capture. From rows 6 and 8, we see that technological spillover has caused changes in regional income and welfare, which reflects on factor income distribution. Comparing India and China, we see that regional income and welfare changes are much higher in case of China. In case of South Asian 
bloc, India is ahead of Sri Lanka and Bangladesh (compare the figures in rows 6 and 8 in respective columns). This is because there are higher doses of spillover from USA into India as compared to other neighboring countries.

We now analyze the effect of such productivity benefits for income inequality as formalized via Equations (20) and (22) in Section 4. Table 9 shows that under both the specifications, the magnitude of initial Gini index falls in value. Comparing Column 1 with both columns 2 and 3 shows that under exponential specification of the 'PROGRESS' parameters, the falls in values of Gini indexes are much sharper. Typically, the regions having relatively higher socio-institutional congruence with the US (and hence, having higher technology appropriation) are capable of reducing income inequality (compare Column 1 with Column 3).

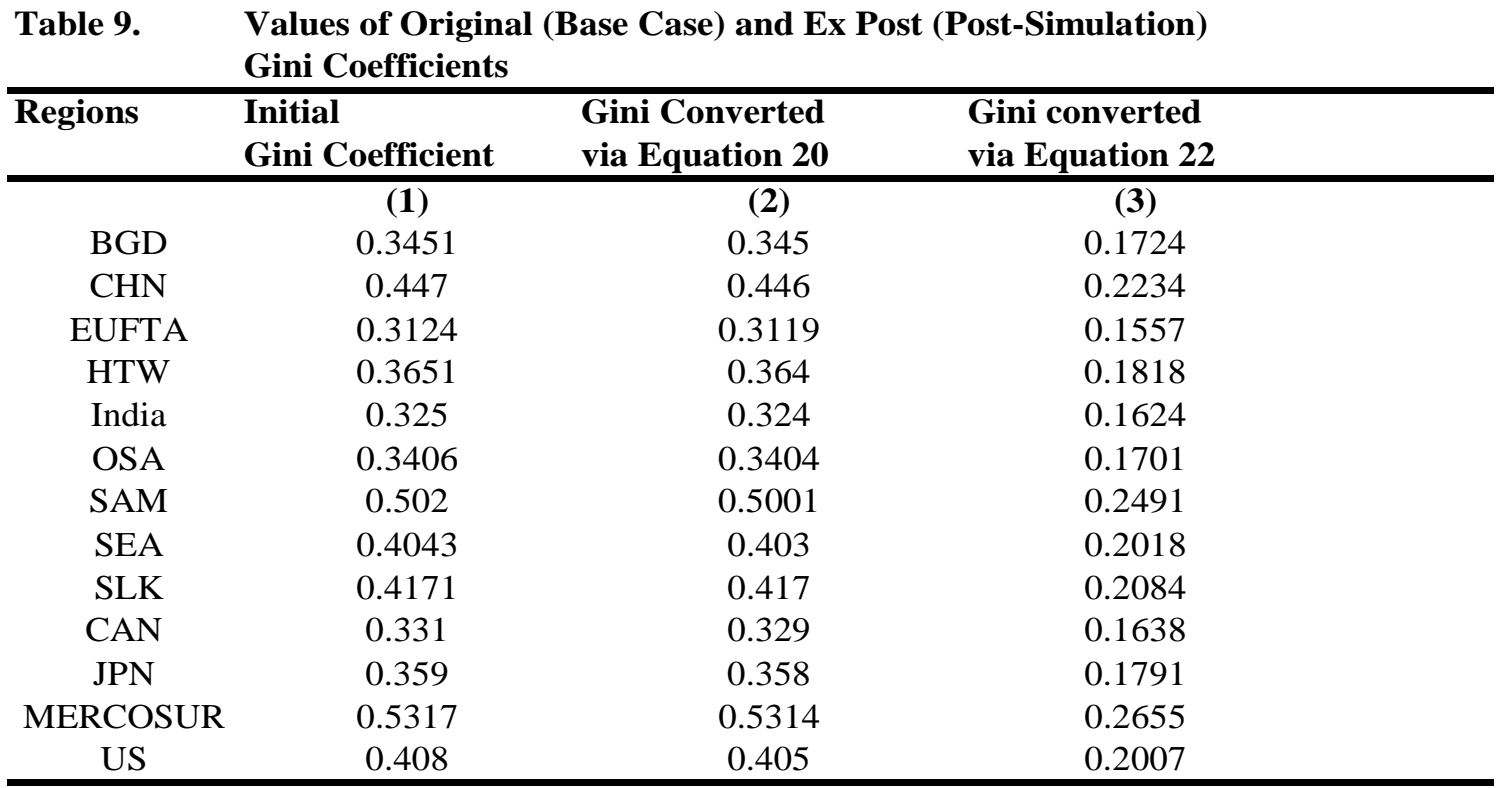

Source: $\quad$ Author's simulations are reported in columns 2 and 3, column 1 is from established datasource of World Bank, WDR 2005 and Deininger and Squire, September 1996

Comparing the rows in Table 9, we can infer that for each region the magnitude of Gini value has registered a decline under productivity spillover scenario. Thus, the regions with higher magnitude of 'TAP' parameter (via Equation 14) are able to reduce the income inequality and income poverty because of conducive growth climate and appropriate constellation of enabling factors like good governance, technological achievement and human development. When constellation of socioinstitutional parameters is optimal such that spillover coefficient is higher, then, following Equation (22), we see that Gini measure of inequality deflates.

\section{B. Scenarios of Trade Policy Configurations}

To offer a comparative enumeration of technology innovation policy in facilitating growth, we consider two generic types of trade liberalization scenarios in the presence of spillover: firstly, under the HAS configuration of trade reform where the Hub, USA, liberalizes trade with spokes India and China simultaneously (non-sequential); then, subsequently, we simulate intra-spoke liberalization. That is, firstly two separate FTAs are simultaneously established: China-U.S. FTA and India-US 
FTA. ${ }^{25}$ Secondly. following the establishment of the HAS system, we simulate the implementation of the regional liberalization in which trade is liberalized between the spokes' economies. ${ }^{26}$ In this scenario, we conjecture that China and India gain directly in the HAS and FTA phases, but that other developing regions like MERCOSUR, South East Asia and Latin America gain indirectly in the multilateral trade liberalization - the reason being, that by simultaneously establishing FTAs with the US, these regions get a head start directly. ${ }^{27}$

\section{Analysis of Results under Combinations of TFP Shock and Trade Reforms}

In the presence of the TFP shock, we simulate a one-shot emergence of a HAS (i.e., USA simultaneously forms FTA with India and with China). The results reported in Table 10 show that the TOT movement preserves the same ranking and order of magnitude except for China and USA who register relatively higher improvement in terms of trade due to preferential market access and resultant rise in trade.

Thus, welfare increases considerably due predominantly to technical change (see rows 6 and 7 in Table 10). Also, China and India are able to register an improved trade balance due to trade creation.

Following the establishment of the HAS, we look at the case in which a more comprehensive regional Indo-China FTA is achieved by freeing trade between the spokes.

In this FTA scenario, the Terms-of-Trade (TOT) falls in India whereas other considered regions maintain the same sign. This is because in the scenario, USA and Canada, which are the biggest benefactors of trade-induced technology flows and which have higher parameters of such capture, are able to appropriate the benefits of market accesses in these two regions. Whilst export diversion occurs between two spokes, it is not substantial and the presence of technology transfer improves welfare. However, under the HAS and Sino-Indian intra-spoke liberalization scenarios, the productivity mechanism and induced spillover reduces income inequality by a small order of magnitude. These values are almost the same as in Table 9 above.

Comparing columns 1 and 3 of Table 9 we see that relative to the initial values of Gini coefficients, ex post Gini values decrease under both HAS and intra-spoke FTA scenarios; also, as compared to

HAS configurations, under the Indo-China FTA scheme the fall in income inequality is a bit more. This is due to indirect spillover under full-fledged liberalization between India and China.

\footnotetext{
25 In terms of the actual policy experiment, we assume that each arrangement consists of an immediate (i.e., no phasing-in), complete (i.e., no excluded sectors and no partial liberalization) and preferential (i.e., no liberalization with non-members) removal of the relevant tariffs and any quantifiable non-tariff barriers.

${ }^{26}$ In particular, using the updated database from the previous experiment, we simulate trade liberalization between the spokes-India and China-to have full-fledged liberalization among the three players.

${ }^{27}$ On the contrary, in a reverse sequence where at first China forms FTA with USA and then with India, the technological benefits will be harnessed by China at later stage only when USA liberalizes trade with her. Blyde (2004) shows empirical supports for such direct and indirect trade-related technology flows.
} 
Table 10. Simulated Regional Effects on Aggregate Performance Without Sequencing

\begin{tabular}{|c|c|c|c|c|c|c|c|c|c|c|}
\hline \multirow{2}{*}{\begin{tabular}{|l} 
Regions \\
Type of configuration $\rightarrow:$
\end{tabular}} & \multicolumn{2}{|l|}{ USA } & \multicolumn{2}{|l|}{ China } & \multicolumn{2}{|l|}{ India } & \multicolumn{2}{|c|}{ South America } & \multicolumn{2}{|l|}{ Canada } \\
\hline & $\begin{array}{l}\text { Joint } \\
\text { HAS } \\
(1)\end{array}$ & $\begin{array}{l}\text { Indo-China } \\
\text { FTA } \\
\text { (2) }\end{array}$ & $\begin{array}{l}\text { Joint } \\
\text { HAS } \\
(1)\end{array}$ & $\begin{array}{l}\text { Indo- } \\
\text { China } \\
\text { FTA } \\
(2)\end{array}$ & $\begin{array}{l}\text { Joint } \\
\text { HAS } \\
(1)\end{array}$ & $\begin{array}{l}\text { Indo- } \\
\text { China } \\
\text { FTA } \\
(2)\end{array}$ & $\begin{array}{l}\text { Joint } \\
\text { HAS } \\
(1)\end{array}$ & $\begin{array}{l}\text { Indo- } \\
\text { China FTA } \\
\text { (2) }\end{array}$ & $\begin{array}{l}\text { Joint } \\
\text { HAS } \\
(1)\end{array}$ & $\begin{array}{l}\text { Indo-China } \\
\text { FTA } \\
\text { (2) }\end{array}$ \\
\hline Changes in $\downarrow$ : & & & & & & & & & & \\
\hline $\begin{array}{l}\text { 1. Terms-of-trade } \\
\text { 2. Aggregate export price }\end{array}$ & 0.64 & 0.19 & 0.92 & 0.24 & 0.07 & -0.27 & -0.16 & 0.14 & -0.32 & 0.15 \\
\hline $\begin{array}{l}\text { index } \\
\text { 3. Aggregate import price }\end{array}$ & -1.06 & -1.35 & -0.79 & -1.35 & -1.56 & -1.80 & -1.62 & -1.37 & -1.66 & -1.30 \\
\hline $\begin{array}{l}\text { index } \\
\text { 4. Regional Household }\end{array}$ & -1.69 & -1.54 & -1.69 & -1.59 & -1.62 & -1.53 & -1.47 & -1.50 & -1.34 & -1.45 \\
\hline Income & 4.06 & 3.97 & 0.74 & 0.30 & 0.21 & 0.20 & 1.81 & 1.89 & 2.31 & 2.48 \\
\hline $\begin{array}{l}\text { 5. Change in trade balance } \\
\text { (in million US\$) }\end{array}$ & -44010.22 & $2-38978.11$ & -374.9 & 2370.9 & 581.33 & 882.83 & 179.36 & -327.09 & -1011.20 & -1246.50 \\
\hline $\begin{array}{l}\text { 6. Welfare (EV) (in million } \\
\text { US\$) } \\
\text { 7. Contribution of TFP to }\end{array}$ & 293090.9 & 295569.9 & 5702.7 & 2322.3 & 773.62 & 721.39 & 13381.0 & 14032.1 & 13111.5 & 14199.4 \\
\hline EV(in million US\$) & 285401.7 & 292745.3 & 1000.1 & 1246.1 & 503.58 & 710.30 & 12267.8 & 12158.7 & 11923.47 & 711926.1 \\
\hline
\end{tabular}

Source: Authors' simulation of impact of 4\% TFP Shock plus joint HAS and FTAA. Note: First 4 rows report results in Percentage changes. Welfare and trade balance changes in rows 5, 6 and 7 are reported in levels.

Compared to the HAS sequences, the FTAA scenario in each case gives much augmentation of capital goods leading to efficiency gains. Below Table 11 reports the sectoral performances behind such growth effect.

From the values of sectoral spillover coefficients (column 3, Table 11), it is evident that in USA sectoral TFP growth is highest in all three sectors as compared to other regions (column 4, Table 11). Having the highest value of the capture parameter, the USA's spillover values are magnified, and this results in higher TFP growth. Similar considerations apply for Canada, EU and South America. However, for the relatively laggard regions China and India with lower magnitudes of $\theta_{\mathrm{r}}$, the resultant sectoral TFP growth is of very low magnitude.

TFP improvement resulted in higher percentage increases in output in all the regions (column 5, Table 11. Cost-saving and consequential decline in supply prices are largely attributable to a decline in the price of composite value-added and its constituents following the TFP shock. However, compared to the HAS sequences, in the full-fledged FTA scenario, India registers much larger falls in prices compared to China, due to direct and indirect transmitted productivity gains, thereby grabbing market access at the expense of China. 
Table 11- Simulated Impact on Sectoral TFP, Output and Spillover Coefficient*

\begin{tabular}{|c|c|c|c|c|}
\hline $\begin{array}{l}\text { Regions } \\
\text { (1) }\end{array}$ & $\begin{array}{l}\text { Sectors } \\
\text { (2) }\end{array}$ & $\begin{array}{l}\text { Spillover } \\
\text { Coefficients } \\
\text { (Base period) } \\
\text { (3) }\end{array}$ & $\begin{array}{l}\text { Sectoral TFP } \\
\text { Growth } \\
\text { (Percentage } \\
\text { changes) } \\
(4)\end{array}$ & $\begin{array}{l}\text { Sectoral Output } \\
\text { (Percentage } \\
\text { changes) } \\
(5) \\
\end{array}$ \\
\hline \multirow[t]{3}{*}{ United States } & LMnfcs & 0.91 & 3.65 & 3.45 \\
\hline & HMnfes & 0.91 & 3.63 & 2.92 \\
\hline & HiTech & 0.88 & 4.00 & 2.48 \\
\hline \multirow[t]{3}{*}{ CAN } & LMnfcs & 0.63 & 2.48 & 2.44 \\
\hline & HMnfcs & 0.59 & 2.34 & 2.23 \\
\hline & HiTech & 0.66 & 2.62 & 2.15 \\
\hline \multirow[t]{3}{*}{ China } & LMnfcs & 0.02 & 0.10 & 0.95 \\
\hline & HMnfcs & 0.03 & 0.13 & 0.39 \\
\hline & HiTech & 0.04 & 0.22 & 0.25 \\
\hline \multirow[t]{3}{*}{ India } & LMnfcs & 0.02 & 0.12 & 0.82 \\
\hline & HMnfcs & 0.02 & 0.12 & 0.13 \\
\hline & HiTech & 0.05 & 0.32 & 0.11 \\
\hline \multirow[t]{3}{*}{ South America } & LMnfcs & 0.47 & 1.85 & 2.05 \\
\hline & HMnfcs & 0.48 & 1.90 & 1.74 \\
\hline & HiTech & 0.50 & 1.99 & 2.15 \\
\hline \multirow[t]{3}{*}{ MERCOSUR } & LMnfcs & 0.04 & 0.16 & 0.68 \\
\hline & HMnfcs & 0.08 & 0.32 & 0.64 \\
\hline & HiTech & 0.14 & 0.56 & 0.43 \\
\hline
\end{tabular}

*Figures in columns 4 and 5 are in percentage changes following TFP shock.

\section{Concluding ReMarks}

Of late, with the rise to prominence of new endogenous growth theory the role of international trade and foreign direct investment in facilitating trans-border technology flows and consequential rises in productivity has been of immense research interest. This has been accentuated by the rising tide of globalization. This paper has examined the effects on intra-national and international disparities in income inequality and poverty in developing regions generated by changes in trade policy configurations between them and a leading source of technological innovation. The latter was taken to be the USA and the developing regions considered were India, South America and China. The dynamism of the high technology clusters (viz., information and communication technology, ICT) in inducing productivity improvement and economic growth has received major attention, both in the literature, and in this paper. For the developing regions, the role of knowledge-capital and its propagation is of utmost importance for their evolution in a growth trajectory on a sustained basis.

In this paper, we have simulated an augmented version of a global CGE model to see the income distributional consequences of such trade-mediated technology spillover. We find considerable welfare gains in each recipient region receiving technological spillovers, embodied in trade flows, from a trade partner that leads innovation. This is in line with the findings of Cline (2004) where estimated static efficiency gains from global free trade are $\$ 90$ billion per annum for the less 
developed regions. According to him, there are dynamic productivity benefits from open trade, where a $1 \%$ increase in trade openness contributes $0.5 \%$ to long-term per capita income. This finding is in broad conformity with our findings.

Moreover, we decipher a mechanism of income inequality reduction facilitated by higher doses of technology appropriation. In other words, a higher constellation of social acceptance, institutional congruence, and better institutional features, helps assimilate the technology spillover, results in productivity growth, and leads to consequential inequality convergence. That is, income inequality falls with increased trade flows and with the higher capture of the consequential transmission of technology. Reduction in income inequality leads to alleviation of poverty. This finding, following our specified theoretical mechanism in the model, is in conformity with Cline (2004), who estimated that taking into account the effects of capital accumulation, trade openness, and productivity growth, the beneficial effects of global free trade would release approximately 540 million people from the poverty trap over the long term. In our model, we find that the incidence of a fall in inequality with global trade openness is aided by associated factors such as better governance, availability of human capital, level of human development, social acceptance and socio-institutional congruence with innovative developed nations having high per capita income. Without these factors, growth associated with higher trade volumes might not reduce inequality. 


\section{REFERENCES}

Amiti, M., and S-J Wei (October 2004). "Fear of Service Outsourcing: Is it Justified?" IMF Working Paper, Research Department, WP/04/186. pp. 1-42.

Anand, Sudhir and Amartya Sen (1997). "Concepts of Human Development and Poverty: A Multidimensional Perspective." In Poverty and Human Development, Human Development Papers. Human Development Report Office. The United Nations Development Programme, NY, USA.

Armington, P.A. (1969). A Theory of Demand for Products Distinguished by Place of Production. IMF Staff Papers 16:159-78.

Autor, David. (November, 2001). "Why do Temporary Help Firms Provide Free General Skills Training?" Quarterly Journal of Economics.

Autor, David. (2002). "Outsourcing at Will: Unjust Dismissal Doctrine and the Growth of Temporary Help Employment.” Journal of Labor Economics.

Barro, R. J. and J. W. Lee (1996). "International Measures of Schooling Years and Schooling Quality." Papers and Proceedings of American Economic Review. 86 (2), pp. 218-223.

Bartel, A., S. Lach, and N. Sicherman (February 2005). "Outsourcing and Technological Change." Working Paper \# 1158, NBER, pp. 1-37.

Bayoumi, T., D. T. Coe, and E. Helpman (1999). R\&D Spillovers and Global Growth. Journal of International Economics 47:399-428.

Berg, A., and A. Krueger (2003). "Trade, Growth, and Poverty-A Selective Survey," Annual World Bank Conference on Development Economics 2003, World Bank.

Bhagwati, J. (1993), Regionalism and Multilateralism: An Overview, J. de Melo and A. Panagariya (eds), New Dimensions in Regional Integration (NY: Cambridge University Press).

Bleaney, Michael and Akira Nishiyama (2004). "Some international evidence on Poverty Alleviation and Economic Growth.” The European Journal of Development Research. 16 (4), pp. 827844.

Bourguignon, Francois (March 2004). "The Poverty-Growth-Inequality Triangle." Working Paper No. 125, Indian council for Research on International Economic Relations, New Delhi, India.

(2003). "The Growth Elasticity of Poverty Reduction: Explaining Heterogeneity across Countries and Time Periods." In T. Eicher and S. Turnovsky, eds. Inequality and Growth: Theory and Policy Implications. Cambridge: MIT Press.

Bussolo, Maurizio and David O'Connor (2002). “Technology and Poverty: Mapping the Connections." In Jorge Braga de Macedo and Tadao Chino (eds.), Technology and Poverty Reduction in Asia and the Pacific. Development Centre Seminars, OECD.

Chakrabarti, A. (2000). "Does Trade Cause Inequality?" Journal of Economic Development, 25(2). 
Cline, W. R. (2004). "Trade Policy and Global Poverty." Centre for Global Development, Institute for International Economics. Washington DC, USA.

Chen, S., and M. Ravallion. (2004). "How Have the World's Poorest Fared since the Early 1980s?" The World Bank Research Observer, 19 (2), World Bank, pp. 141-169.

Coe, D., and E. Helpman (1995). International R\&D Spillovers. European Economic Review 39 (5): 859-87.

Coe, D. T., E. Helpman, and A. W. Hoffmaister (1997). North-South R\&D Spillovers. The Economic Journal 107 (January): 134-49.

Cohen, W. M., and D. A. Levinthal (1989). Innovation and Learning: The Two Faces of R\&D. The Economic Journal 99(September): 569-596.

—and (1990). Absorptive Capacity: A New Perspective on Learning and Innovation. Administrative Science Quarterly 35(1): 128-52.

Das, Gouranga G. (2002). "Trade, Technology and Human Capital: Stylised Facts and Quantitative Evidence"-The World Economy, Volume 25, Issue 2, Blackwell Publishers, Oxford (U.K.) \& Boston (U.S.A.).

De Ferranti, D., G. E. Perry, I. S. Gill, J. L. Guasch, W. F. Maloney, C. S. Paramo, and N. Schady (2003b). Closing the Gap in Education and Technology. The World Bank, Washington.

De, Janvry, A., G. Graff, E. Sadoulet and D. Zilberman (2000), "Technological change in Agriculture and Poverty Reduction," A Concept Paper for the World Development Report on Poverty And Development, 2000/01, World Bank, Washington DC, processed.

De Rosa, D. A. (1998). “ Regional Integration Arrangements: Static Economic Theory, Quantitative Findings, and Policy Guidelines", background paper for a World Bank Policy Research Report, Regionalism and Development, Virginia: ADR International Ltd.

Deininger, K., and L. Squire (1996). "A New Dataset measuring Income Inequality," The World Bank Economic Review 10 (3), pp. 565-591.

Dimaranan, B., and R. A. A. Mc Dougall (eds.) (2003). Global Trade, Assistance, and Protection: The GTAP 5 Database, Center for Global Trade Analysis, Purdue University, USA.

Dollar, David and A. Kraay (2002). "Growth is Good for the Poor." Journal of Economic Growth, 7 , pp. 195-225.

-- (2003). "Institutions, Trade, and Growth." Journal of Monetary Economics, 50(1), pp. 133162.

Dyke, Nancy Berg (2001) in Aspen Institute Conference Report on International Peace, Security and Prosperity (2001), "Attacking Global Poverty: Technology for Economic and Social Uplift." August 18-20, 2000, Aspen, Colorado.

Eaton, J. and S. Kortum (1996). Trade in Ideas: Patenting and Productivity in the OECD. Journal of International Economics 40: 251-278. 
Francois, J. F. and C. R. Shiells (1994), “ AGE Models of North American Free Trade' in J. F. Francois and C. R. Shiells, (eds) Modeling Trade Policy, Applied General Equilibrium Assessments of North American Free Trade, (Cambridge: Cambridge University Press).

Frankel, J. A., and D. romer. (1999). "Does Trade Cause Growth?" American Economic Review (June), pp. 379-399.

Gordon, James and Poonam Gupta (2004). Understanding India's Services Revolution. IMF Working Paper, WP/04/171.

Groot, H. L. F. de., G-J Linders, P. Rietvelda, and U. Subramanian (2004). The Institutional Determinants of Bilateral Trade Patterns. Kyklos 57 (February):103-124.

Gunter, B. G., M. J. Cohen, and H. Lofgren (2005). "Analysing Macro-poverty Linkages: An Overview." Development Policy Review, 23 (3), pp. 243-265.

Harrison, W. J. and K. R. Pearson (1996) "Computing Solutions for Large General Equilibrium Models Using GEMPACK.” Computational Economics, 9: pp. 83-127.

Helpman, E. (2004). "The Mystery of Economic Growth." Harvard University Press.

Hertel, T. W., ed. (1997). Global Trade Analysis: Modeling and Applications. Cambridge, MA, Cambridge University Press.

Hertel, T. W., and J. J. Reimer (November 2004). "Predicting the Poverty Impact of Trade Reform." World Bank Policy Research Working Paper 3444, World Bank.

Huang, J. and S. Rozelle (1996), “Technological Change: Rediscovering the Engine of Productivity Growth in China's Rural Economy." Journal of Development Economics, 49.

Huang, J., R. Hu, H. van Meijl, and F. van Tongeren (2004). "Biotechnology boosts to crop productivity in China: trade and welfare implications." Journal of development Economics, 75, pp. 27-54.

Kaufmann, D. A. Kraay, and M. Mastruzzi (2003). Governance Matters III: Governance Indicators for 1996-2002. World Bank Policy Research Working Paper 3106. Dataset at: www.worldbank.org/wbi/governance/govdata2002/.

Kaufmann, D (2004). Governance Redux: The Empirical Challenge. Chapter in Global Competitiveness Report 2003-2004, World Economic Forum.

Keller, W. (1997). Trade and the Transmission of Technology. NBER Working Paper, 6113, Cambridge, MA, July, 1-33 + Appendix.

(2000). .Do Trade Patterns and Technology Flows affect Productivity Growth? World Bank Economic Review 14: 17-47.

(2001). The Geography and Channels of Diffusion at the World's Technology Frontier. NBER Working Paper, 8150, Cambridge, MA, 1-28 + Appendix. 
(2004). .International Technology Diffusion. Journal of Economic Literature Vol. XLII (September 2004):752-782.

Keynes, J. M. (1930). "Economic Possibilities of Our Grandchildren.”

Milanovic, B., and L. Squire (January 2005). "Does Tariff Liberalization Increase Wage Inequality? Some Empirical Evidence." NBER Working Paper 11046, Massachusetts, Cambridge, USA. Pp. 1-65.

McCulloch, N., L. Alan Winters, and X. Cirera (2001). "Trade Liberalization and Poverty: A Handbook." CEPR and Department for International Development., U.K.

McDougall, R. (October 2003). Release Notes for GTAP.Tab 6.2. GTAP Center, Purdue University, USA.

Meijl, H. van, and F. W. van Tongeren (1998). Trade, Technology Spillovers, and Food Production in China. Weltwirtschaftliches Archiv 134 (3):443-449.

Nelson, R.R. (1990). On Technological Capabilities and their Acquisition. In R.E. Evenson and G. Ranis (eds.), Science and Technology: Lessons for Development Policy, Westview Press.

Pack, H., and L. E. Westphal (1986). "Industrial Strategy and Technological Change: Theory versus Reality." Journal of Development Economics, 87, pp. 87-128.

Ravallion, M. (1994). Poverty Comparisons. Harwood Academic Books. --(1995). "Growth and Poverty: Evidence for Developing Countries in the 1980s." Economics Letters, 48, pp. 411-417. ---(2001). "Growth, Inequality and Poverty: Looking Beyond Averages." World Development. 29(11), pp. 1803-1815.

---(2004). "Looking Beyond Averages in the Trade and Poverty Debate." World Bank Policy Research Working Paper 3461. Washington D.C.: World Bank.

Richardson, J. D. (1995). "Income Inequality and Trade: How to Think, what to Conclude." Journal of Economic Perspectives, 9, pp.33-55.

Robinson, S., and H. Lofgren (2005). " Macro Models and Poverty Analysis: Theoretical Tensions and Empirical Practice. Development Policy Review, 23 (3), pp. 267-283.

Sachs et al. (2004). "Ending Africa’s Poverty Trap.” Brookings Institution.

Sachs, Jeffrey D. (2005) “The End of Poverty: Economic Possibilities of Our Time.” The Penguin Press, New York.

Sen, A. (1993). "Capability and Well-being", in The Quality of Life, (eds.) Martha Nussbaum and A. Sen. Oxford: Clarendon Press.

Sen, A. (2004). "Development as Freedom", Oxford University Press. 
Winters, A. L., N. McCulloch, and A. McKay (March 2004). "Trade Liberalization and Poverty: The Evidence So Far." Journal of Economic Literature, Volume XLII, Number 1, pp. 72—115.

World Bank (1999). Knowledge for Development. World Development Report 1998/9, New York, Oxford University Press.

World Bank (2000). Attacking Poverty. World Development Report 2000/2001, New York, Oxford University Press.

World Bank (2004a). Making Services work for Poor People. World Development Report 2004, New York, Oxford University Press.

World Bank (2004b). Global Economic Prospects 2004: Realizing the Development Promise of the Doha Agenda. Washington D.C.: World Bank.

World Bank (2004c). World Development Indicators. World Bank.

World Bank (2005). A Better Investment Climate for Everyone. World Development Report 2005, New York, Oxford University Press.

UNDP. Human Development Report 2003: Millenium Development Goals: A Compact among Nations to end Human Poverty. New York, Oxford University Press.

Human Development Report 2001: New York, Oxford University Press.

Yitzhaki, Shlomo (2002). "Do we need a Separate Poverty Measurement?" European Journal of Political Economy, 18, pp. 61-85. 